\title{
Syntheses of crowned polyamines using isolable succinimidyl esters of $N$-tritylated linear amino acids and peptides
}

\author{
Nikolaos Tsiakopoulos, ${ }^{a}$ Charilaos Damianakos, ${ }^{a}$ George Karigiannis ${ }^{\text {a }}$ \\ Dimitrios Vahliotis, ${ }^{\mathrm{b}}$ Dionissios Papaioannou, ${ }^{\mathrm{a} *}$ and Giovanni Sindona ${ }^{\mathrm{c}}$ \\ ${ }^{a}$ Department of Chemistry and ${ }^{b}$ Center of Instrumental Analysis , University of Patras, \\ GR-26500 Patras, Greece \\ ${ }^{c}$ Department of Chemistry, University of Calabria, I-87030 Arcavacata di Rende (Cs), Italy \\ E-mail: D.A.Papaioannou@chemistry.upatras.gr
}

\section{Dedicated to Professor Gerasimos J. Karabatsos on the occasion of his $\mathbf{7 0}^{\text {th }}$ birthday}

(received 17 Mar 03; accepted $15 \mathrm{Jul} \mathrm{03;} \mathrm{published} \mathrm{on} \mathrm{the} \mathrm{web} 16 \mathrm{Jul} \mathrm{03)}$

\begin{abstract}
Partial and total syntheses of polyamines incorporating crown ether moieties have been effected using $\mathrm{N}$-tritylated linear amino acids, like $\beta$-alanine ( $\beta \mathrm{Ala})$ and $\gamma$-aminobutyric acid $(\gamma \mathrm{Aba})$, to introduce the $\mathrm{N}-3-\mathrm{C}$ and $\mathrm{N}-4-\mathrm{C}$ polyamine structural units, respectively. The partial syntheses involve the acylation of commercially available crown bearing amino function(s) or aza-oxa crown ethers with the isolable succinimidyl esters of Trt- $\beta$ Ala-OH or Trt- $\beta$ Ala- $\gamma \mathrm{Aba}-\mathrm{OH}$, followed by $\mathrm{LiAlH}_{4}$-mediated reduction of the resulting amides, whereas in the total syntheses the crown and the aza-oxa crown ether moieties are built-up from commercially available starting materials like polyethylene glycols, epichlorohydrin and dibenzylamine.
\end{abstract}

Keywords: Polyamines, crown ethers, aza-oxa crown ethers, amino acids, active esters, protecting groups

\section{Introduction}

Linear polyamines (PAs), like spermidine (SPD) and spermine (SPM) and their conjugates (PACs) with other natural products are widely distributed in the living organisms and are associated with interesting biological functions. For this reason, they have attracted considerable interest, and a variety of PA analogues and PACs have been already synthesized in order to determine structure-activity relationship and to identify possible leads for the development of PA-based pharmaceuticals. ${ }^{1}$ On the other hand, the cyclic oligomers of ethylene oxide, collectively known as crown ethers (CEs), and their analogues and derivatives are widely used for complexing and separating metal or organic cations, as well as in the areas of phase transfer 
catalysis, host-guest and supramolecular chemistry. ${ }^{2}$ Different types of CEs have been synthesized in order to improve their properties and find suitable applications. In addition, a variety of pharmaceutically interesting compounds have been equipped with crown moieties in order to modify their physiological action. ${ }^{3}$ Accordingly, we decided to examine the possibility of introducing CE moieties into PA molecules and study the complexing and biological properties of this new family of organic compounds, which we collectively coin as crowned polyamines (CRPAs). We now wish to report a general method that we have recently developed which facilitates access to CRPAs;. CEs is commercially available ${ }^{4}$ but we have developed alternative methods of preparation. For the introduction of $\mathrm{CE}$ moieties into various polyamine skeletons as the purpose of this work, we have chosen the commercially available aza-oxa CEs 1 and 2 (Figure 1), the lariat aminomethyl CE 3 and the diaminodibenzo-CE 4, a mixture of the isomers $\mathbf{4 a}$ and $\mathbf{4 b}$.
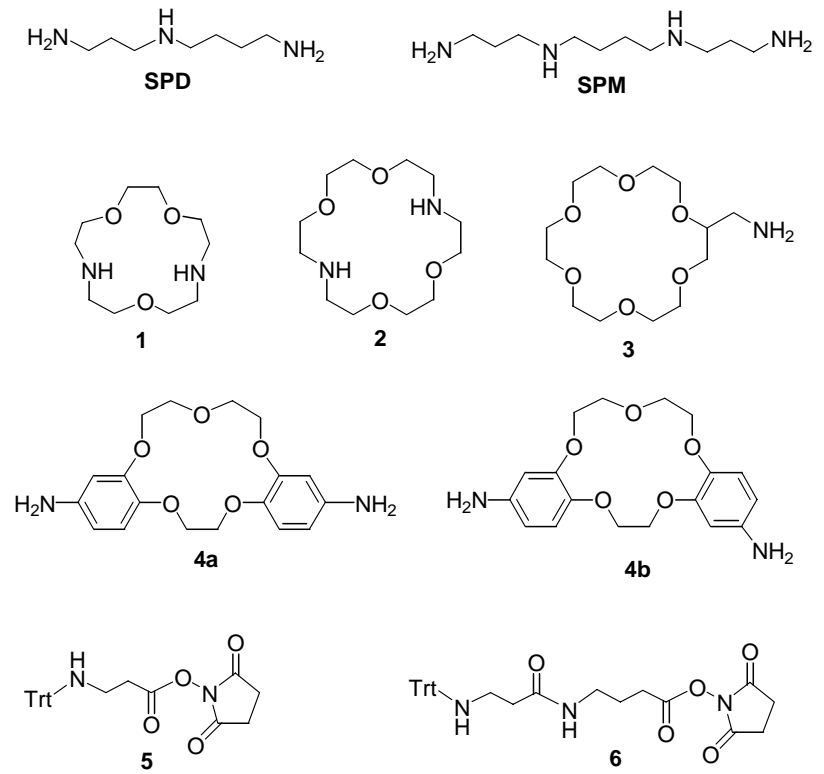

Figure 1. Structures of compounds related to this work.

Furthermore, we used simple commercially available building blocks, like polyethylene glycols, epichlorihydrin, and dibenzylamine, in order to build-up various CE skeletons to the appropriate size and content of $\mathrm{N}$ atoms, and the 'isolable' active esters $\mathbf{5}$ and $\mathbf{6}$, readily available from the corresponding linear amino acids $\beta$-alanine ( $\beta$ Ala) and $\gamma$-aminobutyric acid $(\gamma \mathrm{Aba}){ }^{5}$ as $\mathrm{N}-3-\mathrm{C}$ and $\mathrm{N}-3-\mathrm{C}-\mathrm{N}-4-\mathrm{C}$ synthons for the assembly of various PA skeletons. 


\section{Results and Discussion}

Linear amino acids and $\alpha, \omega$-diaminoalkanes as building blocks for the assembly of linear polyamine skeletons

In a series of letters, ${ }^{5,6}$ we have shown that the triphenylmethyl (trityl, Trt) N-protected linear amino acids, like $\beta$ Ala and $\gamma \mathrm{Aba}$, and their dipeptides, e.g. $\beta A$ la- $\gamma \mathrm{Aba}$, in the form of their corresponding isolable succinimidyl 'active' esters (SAEs) 5 and $\mathbf{6}$ can be successfully employed for the synthesis of a variety of linear and cyclic SPD and SPM analogues and conjugates of the alkaloid kukoamine A type as well as their symmetric and asymmetric dimers, bridged by linear dicarboxylic acids, of the alkaloid tenuilobine type using the 'amide approach ${ }^{4}$. The required SAEs are readily obtained as depicted in Scheme 1.

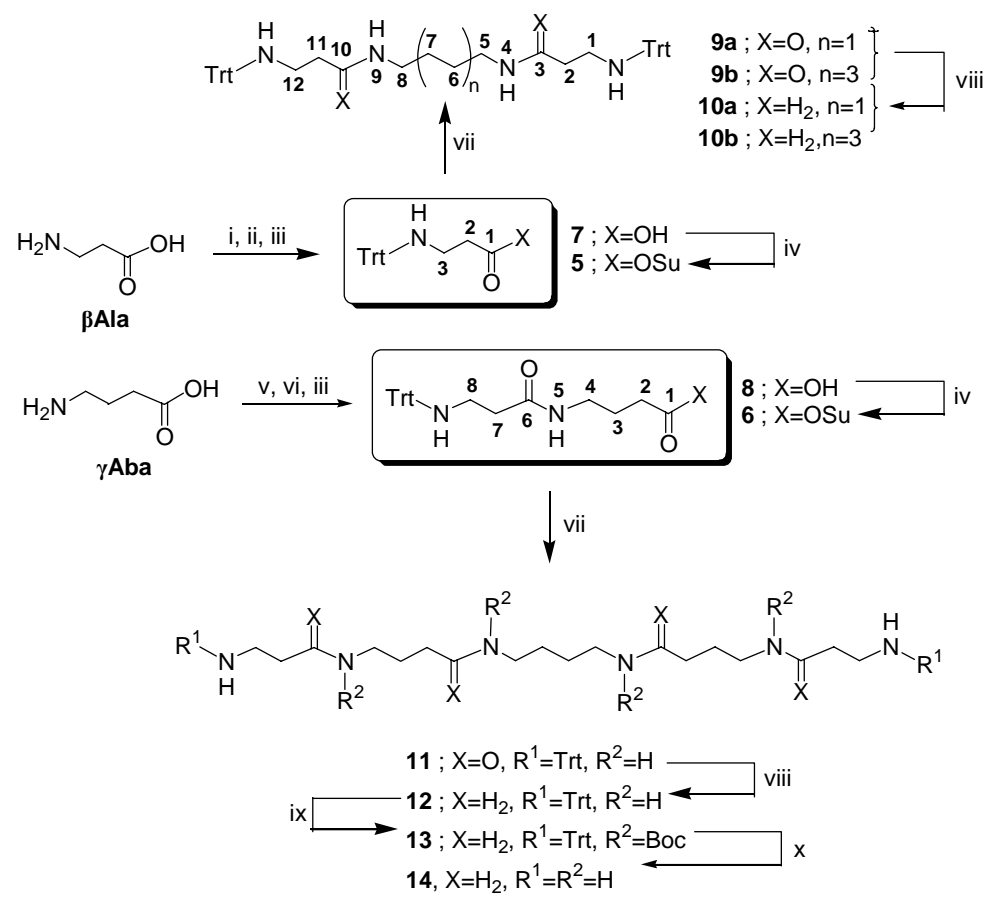

Scheme 1. Syntheses of succinimidyl active esters and of linear polyamines (the numbers on the structures serve for the presentation of the NMR data).

(i) $\mathrm{Me}_{3} \mathrm{SiCl}, \mathrm{CH}_{2} \mathrm{Cl}_{2} / \mathrm{MeCN}$ (5:1), reflux, $30 \mathrm{~min}$. (ii) $\mathrm{Et}_{3} \mathrm{~N} / \mathrm{TrtCl}, 0{ }^{\circ} \mathrm{C}, 1 \mathrm{~h}$ then $25^{\circ} \mathrm{C}, 3 \mathrm{~h}$. (iii) $\mathrm{MeOH}, 97 \%$ (7) or 79\% (8). (iv) HOSu/DCC, THF/DMF (3:1), $0{ }^{\circ} \mathrm{C}, 1 \mathrm{~h}$ then $25^{\circ} \mathrm{C}, 12 \mathrm{~h}, 85 \%$ (5) or $88 \%$ (6). (v) $\mathrm{Me}_{3} \mathrm{SiCl}, \mathrm{CH}_{2} \mathrm{Cl}_{2}, 25{ }^{\circ} \mathrm{C}, 10 \mathrm{~min}$. (vi) 5/Et ${ }_{3} \mathrm{~N}, 0{ }^{\circ} \mathrm{C}, 45 \mathrm{~min}$ then $25{ }^{\circ} \mathrm{C}, 15$ min. (vii) PUT or DAO/Et $3 \mathrm{~N}, \mathrm{DMF}, 25^{\circ} \mathrm{C}, 12-24 \mathrm{~h}, 90 \%$ (9a) or $78 \%$ (9b) or $82 \%$ (11). (viii) $\mathrm{LiAlH}_{4}, \mathrm{THF}$, reflux, 2-4 d; 68\% (10a) or 61\% (10b). (ix) $\mathrm{Boc}_{2} \mathrm{O} / \mathrm{Et}_{3} \mathrm{~N} / \mathrm{cat} \mathrm{DMAP}, \mathrm{CHCl}_{3}, 0{ }^{\circ} \mathrm{C}$, $30 \mathrm{~min}$ then $25^{\circ} \mathrm{C}, 12 \mathrm{~h}, 30 \%$. (x) TFA $/ \mathrm{CH}_{2} \mathrm{Cl}_{2}(1: 1), 25^{\circ} \mathrm{C}, 30 \mathrm{~min}, 75 \%$.

O-Silylation of $\beta$ Ala, followed by $\mathrm{N}$-tritylation and desilylation with $\mathrm{MeOH}^{7}$, provided Trt$\beta$ Ala 7 in $97 \%$ yield. SAE 5 was then obtained in $85 \%$ yield by the condensation of 7 with of $N$ - 
hydroxysuccunimide (HOSu) in the presence of $N, N^{\prime}$-dicyclohexylcarbodiimide (DCC). ${ }^{5 \mathrm{a}}$ On the other hand, O-silylation of $\gamma \mathrm{Aba}$, followed by $\mathrm{N}$-acylation with SAE 5 and desilylation with $\mathrm{MeOH}$ gave the N-tritylated dipeptide 8 in $79 \%$ yield. From this compound, SAE 6 was easily obtained in $88 \%$ yield upon routine activation also with $\mathrm{HOSu}$ in the presence of DCC. ${ }^{5 \mathrm{~b}}$ The applicability of these compounds to build any type of tetra- or hexa-amines of the 3-n-3 or the 34-n-4-3 types was readily exemplified by the facile preparation of the tetra-amine derivatives 10a and 10b ( $\mathrm{n}=4$ and 8, respectively), and the hexa-amine $14(\mathrm{n}=4)$. Thus, condensation of SAE 5 with 1,4-diaminobutane (putrescine, PUT) gave the expected bisamide 9a in 90\% yield. This was then reduced with $\mathrm{LiAlH}_{4}$ to produce $N^{1}, N^{12}-\mathrm{Trt}_{2}-\mathrm{SPM} 10 \mathrm{a}$ in $68 \%$ yield. ${ }^{5 \mathrm{a}}$ Later, the selective direct ditritylation of SPM to produce 10a was reported. ${ }^{8}$ On the other hand, bisacylation of 1,8-diaminooctane (DAO), followed by $\mathrm{LiAlH}_{4}$ reduction of the bisamide $9 \mathbf{b}$ produced the $N^{1}, N^{16}$-ditritylated tetra-amine $\mathbf{1 0 b}$ in $61 \%$ yield. ${ }^{4}$ Similarly, bisacylation of PUT with SAE 6 produced the tetra-amide 11 in $82 \%$ yield. $\mathrm{LiAlH}_{4}$ reduction of all four amide functions took place unexceptionally and the thus obtained crude PA derivative 12 was per-tertbutoxycarbonylated to facilitate purification by flash column chromatography (FCC). The resulting pure, fully protected, hexa-amine 13 (30\% overall yield) was deprotected with a 50\% solution of trifluoroacetic acid (TFA) in $\mathrm{CH}_{2} \mathrm{Cl}_{2}$ to produce the 3-4-4-4-3 hexa-amine 14 as the hexatrifluoroacetate salt, in $75 \%$ yield. ${ }^{4}$ In this general methodology, diversion may readily arise from the linear or even branched (e.g. chiral) amino acids or peptides, and the linear or branched or cyclic $\alpha, \omega$-diaminoalkanes used to furnish the $\mathrm{N}-\mathrm{C}_{\mathrm{n}}-\mathrm{N}$ central core of the polyamine.
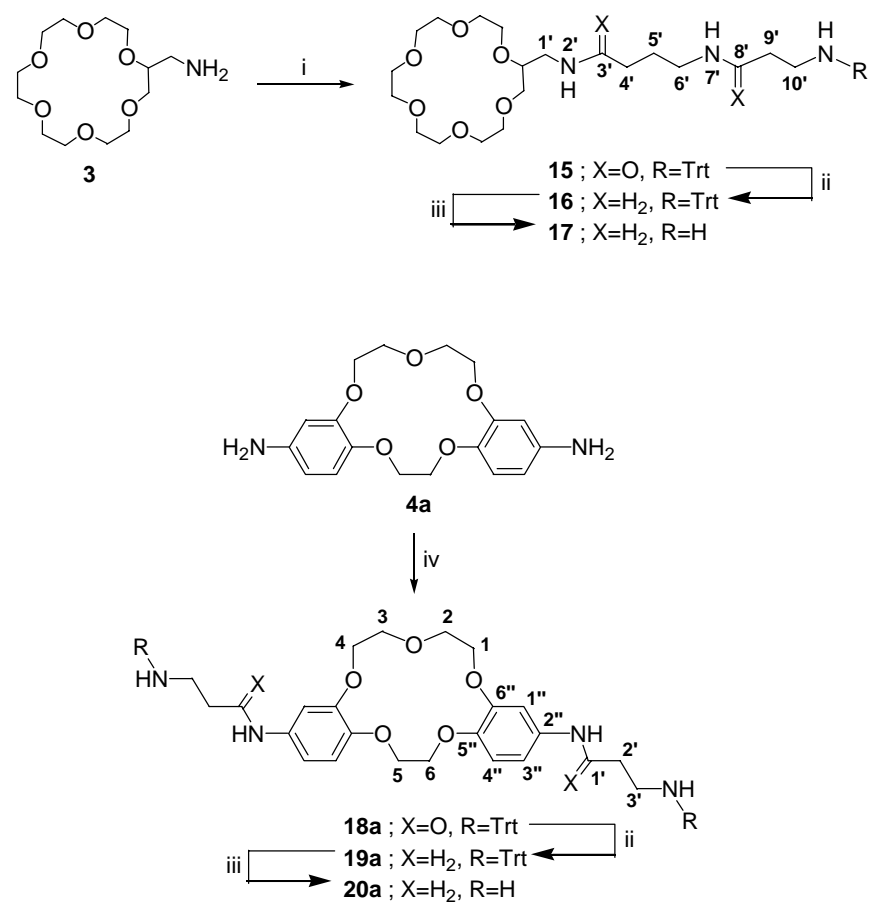

Scheme 2. Partial syntheses of crown ethers incorporating polyamine elements (the numbers on the structures serve for the presentation of the NMR data). 
(i) 6/Et $3 \mathrm{~N}, \mathrm{DMF}, 25^{\circ} \mathrm{C}, 1 \mathrm{~h}, 66 \%$. (ii) $\mathrm{LiAlH}_{4}$, THF, reflux, $12-48 \mathrm{~h}, 45 \%$ (16) or $82 \%$ (19). (iii) TFA $/ \mathrm{CH}_{2} \mathrm{Cl}_{2}(1: 1$ or $1: 3), 25^{\circ} \mathrm{C}, 1 \mathrm{~h}, 73 \%$ (17) or $91 \%$ (20). (iv) $5 /{ }^{\mathrm{i}} \mathrm{Pr}_{2} \mathrm{NEt}$, DMF, $60{ }^{\circ} \mathrm{C}, 3 \mathrm{~h}$, then $25^{\circ} \mathrm{C}, 12 \mathrm{~h}, 55 \%$.

\section{Partial syntheses of polyamines incorporating crown and diaza-oxa crown ether moieties}

Oxapolyamines, i.e. polyamines incorporating $\mathrm{O}$ atom(s) in their skeleton have recently gained considerable interest. ${ }^{9}$ Therefore, we decided to extent the above described method to include the cyclic counterparts of poly(ethylene glycols), i.e. CEs. Two possibilities were examined, namely CEs bearing one or two amino-handles and aza-oxy CEs incorporating two $\mathrm{N}$ atoms within the ring. Accordingly, condensation of 2-aminomethyl-18-CE-6 3 with SAE 6 provided the bisamide 15 in $66 \%$ yield (Scheme 2). $\mathrm{LiAlH}_{4}$ reduction of 15 gave the corresponding N-tritylated PA derivative 16 (45\% yield); upon TFA detritylation the 8-N-monoalkylated SPD analogue 17 was obtained as its tris(trifluoroacetate) salt (73\% yield). Similarly, bisacylation of diaminodibenzo15-CE-5 4 with SAE 5 gave bisamide 18 (only isomer 18a is shown in Scheme 2) in 55\% yield.

Reduction of 18 with $\mathrm{LiAlH}_{4}$, followed by detritylation of the resulting CE derivative 19 (82\%) gave CE 20 (91\%). Compound 20a may be considered as a conformationally restricted dioxa-analogue of the 3-12-3 tetra-amine core. Furthermore, bisacylation of the diaza-oxa-15CE-5 1 with SAE 5 gave the bisamide 21 in 59\% yield (Scheme 3). Upon $\mathrm{LiAlH}_{4}$ reduction of this compound the fully reduced analogue 22 was obtained in $62 \%$ yield.
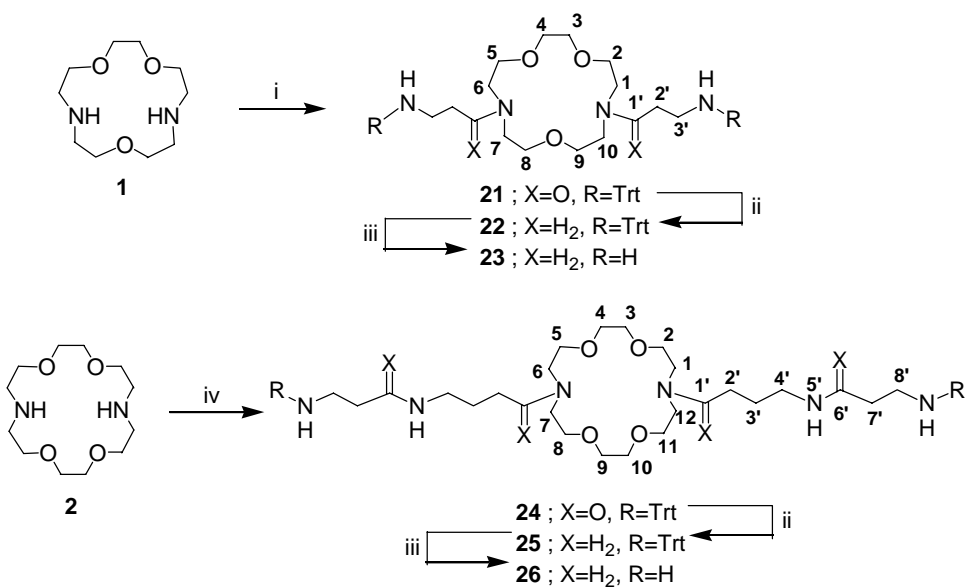

Scheme 3. Partial syntheses of diaza-oxa crown ethers incorporating polyamine elements (the numbers on the structures serve for the presentation of the NMR data).

(i) 5/Et $3 \mathrm{~N} /$ cat. HOBt, $\mathrm{DMF} / \mathrm{CHCl}_{3}(1: 1), 25^{\circ} \mathrm{C}, 12 \mathrm{~h}, 59 \%$. (ii) $\mathrm{LiAlH}_{4}, \mathrm{THF}$, reflux, $1 \mathrm{~d}, 62 \%$ (22) or $64 \%$ (25). (iii) $\mathrm{TFA} / \mathrm{CH}_{2} \mathrm{Cl}_{2}(1: 3), 25^{\circ} \mathrm{C}, 1 \mathrm{~h}, 90 \%$ (23) or (26). (iv) $6 / \mathrm{Et}_{3} \mathrm{~N}, \mathrm{DMF} / \mathrm{CHCl}_{3}$ (3:1), $25^{\circ} \mathrm{C}, 2 \mathrm{~d}, 92 \%$.

Finally, TFA detritylation gave the tetra(trifluoroacetate) salt of CE 23 as in $90 \%$ yield. ${ }^{4}$ This compound may be considered as a crowned oxa-SPM analogue. When SAE 6 was used to bisacylate diaza-oxa-18-CE-6 2, the expected tetra-amide 24 was obtained in $92 \%$ yield. $\mathrm{LiAlH}_{4}$ 
reduction of this compound gave a $64 \%$ yield of $\mathrm{CE}$ derivative 25, from which the hexa(trifluoroacetate) salt of CRPA 26 was obtained in $90 \%$ yield. ${ }^{4}$ This compound may be considered as a dioxa-3-4-8-4-3 PA analogue. It should be noted that the corresponding dioxa-38-3 PA analogue has been obtained by bisalkylation of CE 2 with acrylonitrile and subsequent catalytic hydrogenation over Raney $\mathrm{Ni}^{10}$

\section{Total syntheses of polyamines incorporating crown ether moieties}

Having established the viability of this method we went on to synthesize more complex CRPAs. Taking into consideration the fact that the CEs so far used are commercially available compounds but very expensive for large scale applications, we decided to develop an alternative method for their preparation. For example, we envisaged that aminomethyl CE 3 could be readily produced using as a key-reaction the nucleophilic displacement of the $\mathrm{Cl}$ atom of epichlorohydrin (27) by a synthetically suitable amine. We have used two amines in the past, namely $\mathrm{TrtNH}_{2}{ }^{11}$ and $\mathrm{Bn}_{2} \mathrm{NH},{ }^{5 b}$ to introduce the amino function into the $\gamma$-carboxy group of kainic acid, and at position 8 of SPD, respectively. It should be noted that aminomethyl CEs have been obtained so far either from the corresponding hydroxymethyl CEs through phthalimidation, followed by hydrazinolysis ${ }^{12}$ or displacement of the $\mathrm{Cl}$ atom of chloromethylated glycol or oligoethylene glycols by ammonia or primary amines followed by $\mathrm{CE}$ formation by reaction with the appropriate oligoethylene glycol ditosylates or dichlorides. ${ }^{13}$ In addition, it had been reported that the reaction of hindered amines with 27 leads to either 3azetidinols in fair yields with primary amines and to a variety of products, some of which coming from EtOH used as the reaction solvent, with secondary amines. ${ }^{14}$ To avoid these solvent-induced side-reactions we performed our exploratory experiments in $\mathbf{2 7}$ as the reaction medium. Much cleaner and reproducible results we obtained with $\mathrm{Bn}_{2} \mathrm{NH}$ in place of $\mathrm{TrtNH}_{2}$, and therefore, we used $\mathrm{Bn}_{2} \mathrm{NH}$ for the preparation of aminomethyl CEs.

In fact, reaction of $\mathrm{Bn}_{2} \mathrm{NH}$ with 27 in the presence of ${ }^{\mathrm{i}} \mathrm{Pr}_{2} \mathrm{NEt}$ as $\mathrm{HCl}$ scavenger, at $110^{\circ} \mathrm{C}$ for $2 \mathrm{~h}$ produced a mixture of two compounds which were readily separated in a small scale experiment by FCC and identified as the chlorohydrin $\mathbf{2 8}$ and the epoxide 29 (Scheme 4). Although this reaction mixture would have been used as such for the following transformation, namely the reaction with an oligoethylene glycol (OEG) in the presence of $\mathrm{NaH}$, much better results were obtained when this mixture (ratio $\mathbf{2 8 : 2 9}=3: 2$; or 2:3) by NMR, was first cleanly converted to the epoxide 29 (67\% overall yield based on $\left.\mathrm{Bn}_{2} \mathrm{NH}\right)$ by treatment with $\mathrm{NaH}$ in THF at ambient temperature. $\mathrm{NaH}$-catalyzed nucleophilic ring-opening of epoxides by OEGs have been used for the production of higher homologues of OEGs, suitable for CEs preparation. ${ }^{15}$ Thus, treatment of epoxide 29 with diethylene glycol (DEG) in the presence of a catalytic quantity of $\mathrm{NaH}$ at refluxing THF for 2 days produced the anticipated triethylene glycol (TEG) derivative 30 in 75\% yield. Preparation of the desired aminomethyl CE derivative 31 required as the final step the condensation of diol $\mathbf{3 0}$ with triethylene glycol ditosylate (TGT). Although several OEG ditosylates are commercially available, we used for the large scale preparation of DGT the method prescribed in ref. 2d, p. 84, an adaptation of the method by Ouchi et al, ${ }^{16}$ TGT 
and tetraethylene glycol ditosylate (TEGT; for its application cf. the following discussion). This method involves treatment of OEGs with tosyl chloride in the presence of $\mathrm{NaOH}$ in a mixture of $\mathrm{THF} / \mathrm{H}_{2} \mathrm{O}(2: 1)$ as the solvent. On the other hand, an improved method has been recently published for the preparation of CEs exploiting the significant enhancement of the alkylation efficiency of alkoxides by ditosylates by using an unwashed $60 \% \mathrm{NaH}$ dispersion in anhydrous DMSO. ${ }^{17}$

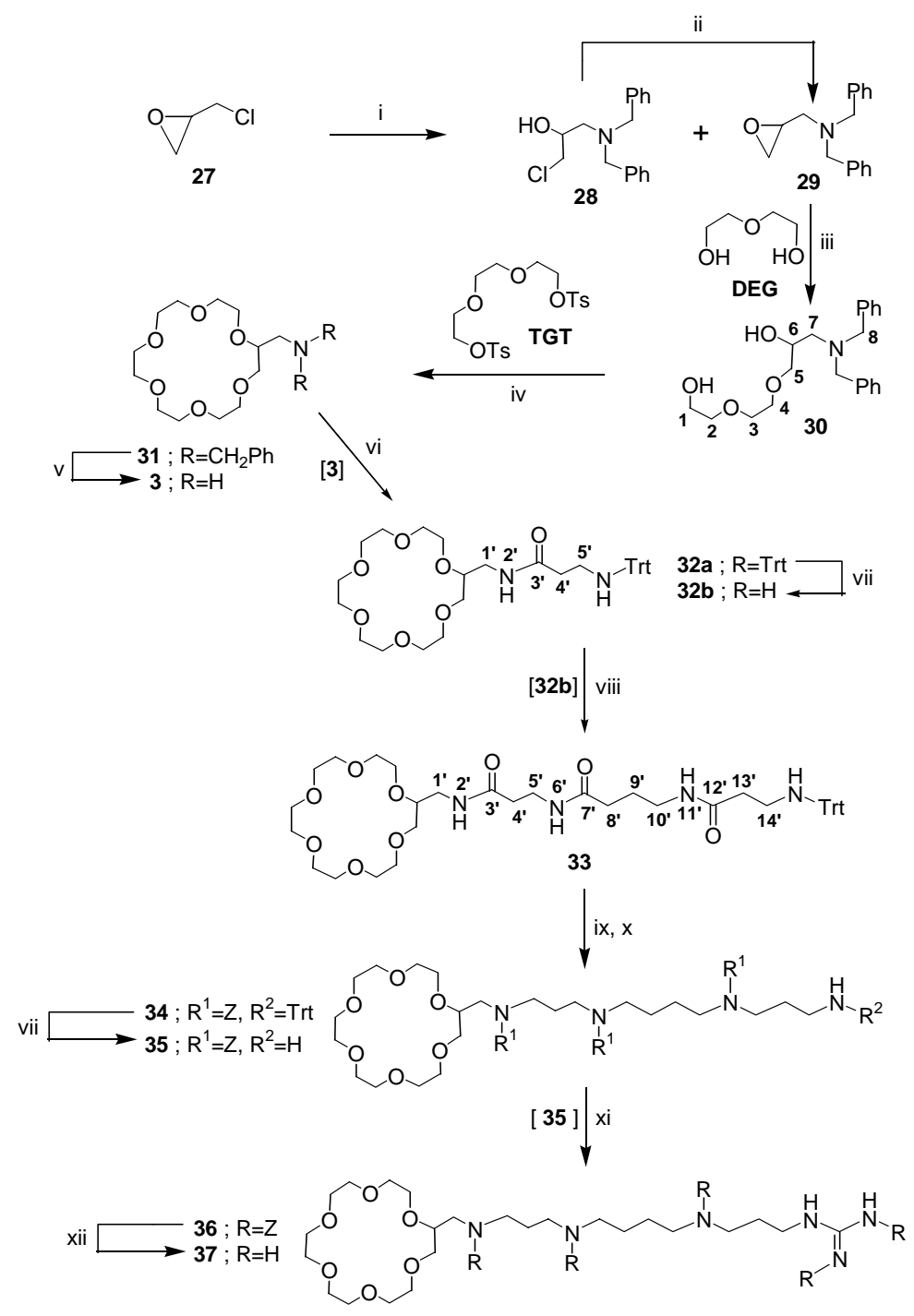

Scheme 4. Total synthesis of 2-aminomethyl-16-CE-6 and of related crowned polyamines (the numbers on the structures serve for the presentation of the NMR data).

(i) $\mathrm{Bn}_{2} \mathrm{NH} / \mathrm{Pr}_{2} \mathrm{NEt}, 110{ }^{\circ} \mathrm{C}, 2 \mathrm{~h}, 40 \% 28$ and $27 \%$ 29. (ii) $\mathrm{NaH} /$ cat. imidazole, $\mathrm{THF}, 25^{\circ} \mathrm{C}, 1 \mathrm{~h}$, $100 \%$. (iii) $\mathrm{NaH}$, THF, reflux, $2 \mathrm{~d}, 75 \%$. (iv) $60 \% \mathrm{NaH}$ dispersion, DMSO, $25{ }^{\circ} \mathrm{C}, 2 \mathrm{~d}, 57 \%$. (v) $\mathrm{H}_{2}(3 \mathrm{~atm}) / \mathrm{Pd}(\mathrm{OH})_{2}$ on $\mathrm{C}, \mathrm{MeOH}, 25^{\circ} \mathrm{C}, 3 \mathrm{~d}, 96 \%$. (vi) 5/Et $3 \mathrm{~N}, \mathrm{DMF}, 25{ }^{\circ} \mathrm{C}, 12 \mathrm{~h}, 93 \%$. (vii) TFA/ $\mathrm{CH}_{2} \mathrm{Cl}_{2}(1: 1), 25^{\circ} \mathrm{C}, 30 \mathrm{~min}, 95 \%$ 32b or $85 \%$ 35. (viii) $6 / \mathrm{Et}_{3} \mathrm{~N}, \mathrm{DMF}, 0{ }^{\circ} \mathrm{C}, 1 \mathrm{~h}$ then $25^{\circ} \mathrm{C}, 1$ d, 79\%. (ix) $\mathrm{LiAlH}_{4}$, THF, reflux, $4 \mathrm{~d}$. (x) $\mathrm{ZCl} / \mathrm{iPr}{ }_{2} \mathrm{NEt}, \mathrm{CHCl}_{3}, 0{ }^{\circ} \mathrm{C}, 30 \mathrm{~min}$ then $25^{\circ} \mathrm{C}, 12 \mathrm{~h}, 60 \%$. 
(xi) $\mathrm{MeS}-\mathrm{C}(=\mathrm{NZ})-\mathrm{NHZ} /{ }^{\mathrm{i}} \mathrm{Pr}_{2} \mathrm{NEt}, \mathrm{CHCl}_{3}, 0{ }^{\circ} \mathrm{C}, 30 \mathrm{~min}$ then $25^{\circ} \mathrm{C}, 12 \mathrm{~h}, 82 \%$. (xii) $\mathrm{H}_{2}(1 \mathrm{~atm}) / 10 \%$ $\mathrm{Pd}-\mathrm{C}, \mathrm{AcOH} / \mathrm{MeOH} / \mathrm{H}_{2} \mathrm{O}(4: 1: 0.1), 25^{\circ} \mathrm{C}, 6 \mathrm{~h}$, then $\mathrm{HCl} / \mathrm{MeOH}, 70 \%$.

Indeed, using this method, the anticipated compound 31 was obtained in 57\% yield. From this compound, the amino function was unmasked by catalytic hydrogenolysis at 3 atm and ambient temperature, using Pearlman's catalyst $\left[\mathrm{Pd}(\mathrm{OH})_{2}\right.$ on $\left.\mathrm{C}\right]$ to remove both benzyl groups. $^{5 \mathrm{~b}, 6 \mathrm{~b}}$

The aminomethyl CE 3 (obtained in 96\% yield) was acylated without any further purification by SAE 5 to introduce the first N-3-C-N unit of SPM into CE. FCC purification afforded amide 32a in $93 \%$ yield. This compound was detritylated with a solution of TFA in $\mathrm{CH}_{2} \mathrm{Cl}_{2}$, and the amino function was acylated with SAE 6 in the presence of $\mathrm{Et}_{3} \mathrm{~N}$ in order to introduce the remaining $4-\mathrm{C}-\mathrm{N}-3-\mathrm{C}-\mathrm{N}$ of SPM into CE. The expected trisamide $\mathbf{3 3}$ was obtained in $75 \%$ overall yield. Reduction of this amide with $\mathrm{LiAlH}_{4}$, followed by complete benzyloxycarbonylation with benzyloxycarbonyl chloride $(\mathrm{ZCl})$ produced the fully protected crowned SPM (CRSPM) 34 in 60\% overall yield. ${ }^{4}$ Complete benzyloxycarbonylation serves two purposes. It facilitates purification by FCC of the crude product produced by $\mathrm{LiAlH}_{4}$ reduction of the amide functions and allows selective removal of the Trt group in the presence of the $Z$ groups by mild acidolysis for further primary amino function modifications. For example, detritylation of CRSPM derivative $\mathbf{3 4}$ followed by guanidylation of the free primary amino group with the commercially available reagent 1,3-bis(benzyloxycarbonyl)-2-methyl-2-thiopseudourea (BZMTU) produced the fully protected guanidylated CRSPM derivative $\mathbf{3 6}$ in $70 \%$ yield. Complete deprotection is then readily effected by catalytic hydrogenolysis to produce the final product, the guanidylated CRSPM 37 in 70\% yield. Natural and synthetic guanidylated polyamines $^{1 \mathrm{a}}$ and other types of organic compounds incorporating the guanidinium function ${ }^{18}$ show very interesting biological properties, due to the fact that this function interacts strongly through hydrogen bonds and electrostatic interactions with other functional groups present in enzymes or receptors.

We then decided to synthesize diaza-oxa CEs incorporating PA elements in their skeleton, such as the CRPAs 23, 43, 48 and 51 (Scheme 5). We envisaged that CEs of this type might be readily available from a common precursor, i.e. the ditritylated oxo-SPM analogue $\mathbf{4 1}$, by alkylation with various OEG diiodides (OEGIs). We based our reasoning on a well-established methodology (the Dale reaction) to produce aza-oxa CEs through the alkylation of primary or secondary diamines by OEGIs in the presence of anhydrous $\mathrm{Na}_{2} \mathrm{CO}_{3}{ }^{19}$ OEGIs are readily available from the corresponding ditosylates OEGTs through the classical displacement with $\mathrm{NaI}$ in acetone (see experimental section) whereas oxa-SPM derivative would be assembled from the diamine 39 and SAE 5. Although several OEG $\alpha, \omega$-diamines (OEGAs) are commercially available, we obtained the required OEGA 39 from DGT through the classical two-steps sequence involving displacement with potassium phthalimide, followed by hydrazinolysis. For the purpose of this work, we isolated the bisphthalylhydrazide salt of OEGA 39 and used it as such for the coupling with SAE 5 in the presence of $\mathrm{Et}_{3} \mathrm{~N}$. The expected bisamide $\mathbf{4 0}$ was 
obtained in 77\% yield. $\mathrm{LiAlH}_{4}$ reduction of bisamide $\mathbf{4 0}$ proceeded unexceptionally to give the key-intermediate $\mathbf{4 1}$ in $85 \%$ yield. Bisalkylation of this intermediate with TGI in dry MeCN in the presence of anhydrous $\mathrm{Na}_{2} \mathrm{CO}_{3}$ produced ditritylated CRPA 22 in very good yield (73\%), whereas its bisalkylation by TEGI in the presence of anhydrous $\mathrm{K}_{2} \mathrm{CO}_{3}$ gave access to the next higher CE homologue 42 in 66\% yield. These CEs incorporate a symmetric oxa-3-5-3 tetraamine skeleton and can be considered as oxa-SPM analogues.

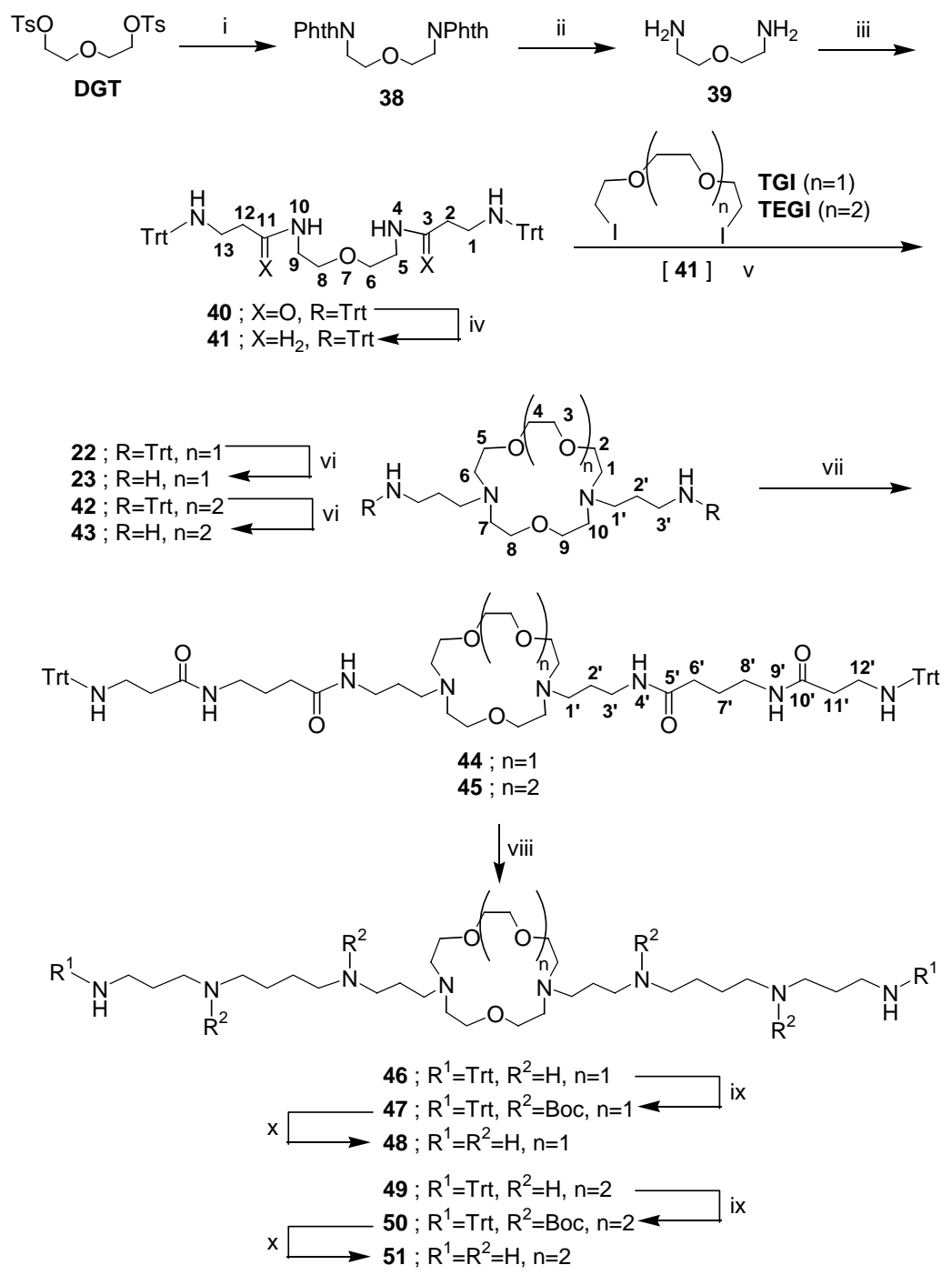

Scheme 5. Total syntheses of diaza-oxa crowned polyamines. (the numbers on the structures serve for the presentation of the NMR data).

(i) PhthNK, DMF, $100-120{ }^{\circ} \mathrm{C}, 12 \mathrm{~h}, 50 \%$. (ii) $\mathrm{H}_{2} \mathrm{NNH}_{2} \cdot \mathrm{H}_{2} \mathrm{O}, \mathrm{MeOH}$, reflux, 30 min, 69\%. (iii) $\mathrm{SAE} 5 / \mathrm{Et}_{3} \mathrm{~N}, \mathrm{DMF}, 0{ }^{\circ} \mathrm{C}, 30 \mathrm{~min}$ then $25^{\circ} \mathrm{C}, 12 \mathrm{~h}, 77 \%$. (iv) $\mathrm{LiAlH}_{4}, \mathrm{THF}$, reflux, $2 \mathrm{~d}, 85 \%$. (v) $\mathrm{Na}_{2} \mathrm{CO}_{3}$ (TGI) or $\mathrm{K}_{2} \mathrm{CO}_{3}$ (TEGI), MeCN, reflux, $2 \mathrm{~d}$, 73\% (22) or $66 \%$ (42). (vi) $\mathrm{TFA} / \mathrm{CH}_{2} \mathrm{Cl}_{2}$ (1:3), $1 \mathrm{~h}, 25{ }^{\circ} \mathrm{C}, 90-100 \%$. (vii) SAE 6/Et $3 \mathrm{~N}$, DMF, $0{ }^{\circ} \mathrm{C}, 30$ min then $25{ }^{\circ} \mathrm{C}, 1 \mathrm{~d}, 68 \%$ (44) or $55 \%$ 
(45). (viii) $\mathrm{LiAlH}_{4}, \mathrm{THF}$, reflux, $4 \mathrm{~d}$. (ix) $\mathrm{Boc}_{2} \mathrm{O} / \mathrm{Et}_{3} \mathrm{~N} /$ cat. DMPA, $\mathrm{CHCl}_{3}, 0{ }^{\circ} \mathrm{C}, 15$ min then $25{ }^{\circ} \mathrm{C}$, $12 \mathrm{~h}, 35 \%$ (47) or $26 \%$ (50). (x) TFA $/ \mathrm{CH}_{2} \mathrm{Cl}_{2}(1: 1), 20 \mathrm{~min}, 25{ }^{\circ} \mathrm{C}, 83-88 \%$.

Detritylation of these compounds provided the corresponding CRPAs 23 and 43, which upon coupling with the SAE 6, also in the presence of $\mathrm{Et}_{3} \mathrm{~N}$, gave the tetra-amides 44 and 45 in 68 and $55 \%$ yield, respectively. These tetra-amides were subsequently reduced with $\mathrm{LiAlH}_{4}$ at refluxing THF to produce the corresponding crude ditritylated CRPAs 46 and 49. For purification by FCC, these compounds were per-tert-butoxycarbonylated with bis(tert-butyl)dicarbonate $\left(\mathrm{Boc}_{2} \mathrm{O}\right)$ in the presence of a catalytic amount of 4-(dimethylamino)pyridine (DMAP) to give the fully protected CRPAs 47 and 50 in $35 \%$ and $26 \%$ overall yields, respectively, based on the starting tetra-amides. Finally, TFA-mediated detritylation of these intermediates gave the desired CRPAs 48 and 51 in $88 \%$ and 83\% yield, respectively. These CEs incorporate a symmetric oxa-3-4-3-53-4-3 octa-amine skeleton.

\section{Conclusions}

Linear and crowned polyamines of variable length or ring-sizes and number of nitrogen functions in their skeleton can be readily assembled using the isolable succinimidyl active esters of the $N$-tritylated amino acid $\beta$ Ala and peptide $\beta$ Ala- $\gamma$ Aba to couple to $\alpha, \omega$-diamino-alkanes and -dibenzocrown ethers, diaza-oxa crown ethers and aminomethyl crown ethers, followed by $\mathrm{LiAlH}_{4}$-mediated reduction of the thus obtained polyamides. The required amino components were either commercially available or were readily synthesized in our laboratory employing, also commercially available, building blocks like oligoethylene glycols, epichlorohydrin and dibenzylamine and the alkylation of either oligoethylene alkoxides by oligoethylene tosylates or oligoethylene diamines by oligoethylene diiodides as key-reactions for the assembly of the crown or diaza-oxa crown ether skeleta, respectively. Further applications of this general approach to the synthesis of other types of crowned polyamines and conjugates and the evaluation of the metal-complexing and biological properties of the novel crowned polyamines described in this work are currently under investigation.

\section{Experimental Section}

General Procedures. Melting points were determined with a Buchi SMP-20 apparatus and are uncorrected. IR spectra were recorded for $\mathrm{KBr}$ pellets on a Perkin Elmer 16PC FT-IR spectrophotometer. ${ }^{1} \mathrm{H}-\mathrm{NMR}$ spectra were obtained at $400.13 \mathrm{MHz}$ and ${ }^{13} \mathrm{C}-\mathrm{NMR}$ spectra at 100.62 $\mathrm{MHz}$ on a Bruker DPX spectrometer. $\mathrm{CDCl}_{3}$ and tetramethylsilane (TMS) were used as the solvent and internal standard, respectively, unless otherwise stated. Chemical shifts are reported in $\delta$ units, parts per million () downfield from TMS. The assignments of the ${ }^{1} \mathrm{H}$ spectra 
are based on chemical shift arguments, analysis of coupling patterns and signal intensities whereas the ${ }^{13} \mathrm{C}$ spectra were assigned taking into consideration chemical shift arguments. Data for the aromatic region (trityl group) are omitted for ${ }^{1} \mathrm{H}$ and ${ }^{13} \mathrm{C}$ NMR spectra of the $N$-tritylated compounds for the sake of brevity. The values observed for compound 7 are typical: ${ }^{1} \mathrm{H}$ NMR: $\delta$ $7.417(6 \mathrm{H}, \mathrm{d}, J=8.0 \mathrm{~Hz}, o-\mathrm{H}), 7.268(6 \mathrm{H}, \mathrm{t}, J=7.6 \mathrm{~Hz}, m-\mathrm{H}), 7.191(3 \mathrm{H}, \mathrm{t}, J=7.2 \mathrm{~Hz}, p-\mathrm{H}) .{ }^{13} \mathrm{C}$ NMR: $\delta 146.321$ (ipso-C), 128.957 (o-C), 128.460 ( $m$-C), 126.630 ( $p$-C).

Electron-impact ionization mass spectra (EI-MS) were obrtained on a Fisons VG 7070E mass spectrometer with electron beam energy of $70 \mathrm{eV}$. Fast atom bombardment (FAB) mass spectra were recorded on a Fisons VG ZAB $2 \mathrm{~F}$ operating at an accelerating potential of $8 \mathrm{kV}$ and neutral xenon beam of $9 \mathrm{eV}$ and using $m$-nitrobenzyl alcohol (NBA) as the matrix. Liquid secondary ion ionization (LSI) mass spectra in the positive mode were obtained on a Fisons VG ZAB-T four-sector instrument. The compounds were ionized using a caesium ion gun operated at an acceleration voltage of $30 \mathrm{kV}$. NBA was also used as the matrix solution which was carefully mixed with a $1 \mu \mathrm{L}$ of sample solution in $\mathrm{CHCl}_{3}$ on the tip of the probe prior to analysis. Electron-spray ionization (ESI) mass spectra were recorded on a Micromass-Platform LC spectrometer using $\mathrm{MeOH}$ or $\mathrm{MeCN}$ as solvents. The ESI high-resolution MS (HR-MS) experiments were carried out in a hybrid QqTOF mass spectrometer equipped with an ion spray ionization source. Compounds were dissolved in a solution containing $0.1 \%$ acetic acid in methanol/water $50 / 50$ and analyzed by direct infusion $(5 \mathrm{~L} / \mathrm{min})$ at the optimum ion spray voltage of $4800 \mathrm{~V}$. The nitrogen gas flow was set at $30 \mathrm{psi}$, whereas the orifice, the focusing ring and the skimmer voltages were kept at 30,50 and $25 \mathrm{~V}$, respectively. MS/MS experiments were performed in the collision cell $q$ on the isotopically pure $\left({ }^{12} \mathrm{C}\right)$ peak of the selected precursor ions by keeping the Q1 at 20 or $30 \mathrm{~V}$ and unit resolution, and scanning the TOF analyser. All the acquisitions were averaged over 50 scans at 8000 TOF resolution with a standard deviation of $0.01 \mathrm{cps}$. Microanalyses were performed on a Carlo Erba EA 1108 CHNS elemental analyzer in the Center of Instrumental Analysis of the University of Patras.

Flash column chromatography (FCC) was performed on Merck silica gel 60 (230-400 mesh) and TLC on 60 Merck $60 \mathrm{~F}_{254}$ films $(0.2 \mathrm{~mm})$ precoated on aluminium foil. The solvent or solvent systems used for elution were: (A) PhMe/EtOAc (98:2), (B) PhMe/EtOAc (8:2), (C) $\mathrm{PhMe} / \mathrm{EtOAc}$ (1:1), (D) $\mathrm{PhMe} / \mathrm{EtOAc}$ (4:6), (E) EtOAc, (F) $\mathrm{CHCl}_{3} / \mathrm{MeOH}$ (95:5), (G) $\mathrm{CHCl}_{3} / \mathrm{MeOH}$ (9:1), (H) $\mathrm{CHCl}_{3} / \mathrm{MeOH} /$ conc. $\mathrm{NH}_{3}$ (95:5:0.5), (I) $\mathrm{CHCl}_{3} / \mathrm{MeOH} /$ conc. $\mathrm{NH}_{3}$ (9:1:0.05), (J) $\mathrm{CHCl}_{3} / \mathrm{MeOH} /$ conc. $\mathrm{NH}_{3}$ (9:1:0.1), (K) $\mathrm{CHCl}_{3} / \mathrm{MeOH} /$ conc. $\mathrm{NH}_{3}$ (85:15:1.5), (L) $\mathrm{CHCl}_{3} / \mathrm{MeOH} /$ conc. $\quad \mathrm{NH}_{3} \quad(8: 2: 0.2), \quad(\mathrm{M}) \quad \mathrm{CHCl}_{3} / \mathrm{MeOH} /$ conc. $\quad \mathrm{NH}_{3} \quad(9: 2.5: 0.2), \quad(\mathrm{N})$ $\mathrm{CHCl}_{3} / \mathrm{MeOH} /$ conc. $\mathrm{NH}_{3}$ (7:3:0.3), (O) $\mathrm{CHCl}_{3} / \mathrm{MeOH} /$ conc. $\mathrm{NH}_{3}$ (6:4:0.4). Spots were visualized with UV light at $254 \mathrm{~nm}$ and the ninhydrin agent. All solvents (Merck) were dried and/or purified according to standard procedures prior to use. Anhydrous $\mathrm{Na}_{2} \mathrm{SO}_{4}$ was used for drying organic solvents, unless otherwise indicated, and subsequently solvents were routinely removed at ca. $40{ }^{\circ} \mathrm{C}$ under reduced pressure (water aspirator). All reagents employed in the present work were purchased from either Aldrich or Fluka and used without further purification. $\mathrm{NaH}$ was purchased as a $60 \%$ dispersion in mineral oil. It was routinely washed off oil by 
repeated washings with hexane prior to use, unless otherwise stated. With the exception of TFAmediated deprotections, all other reactions were routinely carried out in an atmosphere of Ar.

$\mathrm{N}$-Trityl- $\beta$-alanine (7). To a magnetically stirred suspension of $\beta$ Ala $(17.82 \mathrm{~g}, 0.2 \mathrm{~mol})$ in anhydrous $\mathrm{CH}_{2} \mathrm{Cl}_{2}(250 \mathrm{~mL})$ and $\mathrm{MeCN}(50 \mathrm{~mL})$ was added $\mathrm{Me}_{3} \mathrm{SiCl}(27.9 \mathrm{~mL}, 0.22 \mathrm{~mol})$, and the reaction mixture was refluxed with exclusion of moisture for $30 \mathrm{~min}$. To the ice-cooled $\left(0{ }^{\circ} \mathrm{C}\right)$ resulting solution anhydrous $\mathrm{Et}_{3} \mathrm{~N}(61 \mathrm{~mL}, 0.44 \mathrm{~mol})$ was added dropwise followed by the addition of $\mathrm{TrtCl}(58.5 \mathrm{~g}, 0.21 \mathrm{~mol})$ in three equal portions within $15 \mathrm{~min}$. Stirring was continued at $0{ }^{\circ} \mathrm{C}$ for $1 \mathrm{~h}$, and at ambient temperature for $3 \mathrm{~h}$. $\mathrm{MeOH}(20 \mathrm{~mL})$ was then introduced into the reaction mixture and the solvents were evaporated to dryness. To the resulting residue, aqueous $\mathrm{NaOH}$ solution $(1 \mathrm{~N}, 700 \mathrm{~mL})$ was added and then extracted twice with $\mathrm{Et}_{2} \mathrm{O}$. The aqueous phase was then ice-cooled and brought to $\mathrm{pH} 5$ by the dropwise addition of glacial $\mathrm{AcOH}$. A 5\% aqueous citric acid solution was then added to further acidify the reaction mixture until no more precipitate was formed. The precipitate was filtered and washed on the filter twice with $\mathrm{H}_{2} \mathrm{O}$ and then with ice-cold $\mathrm{Et}_{2} \mathrm{O}$ and finally dried under vacuo at $40{ }^{\circ} \mathrm{C}$ overnight to give pure product 7 (64.3 g. 97\%), mp 166-69 ${ }^{\circ} \mathrm{C}$; $\mathrm{R}_{\mathrm{f}}(\mathrm{G})$ 0.33. FT-IR: 3455-2500 (CO-OH), 3298 (NH-Trt), 1708 (CO-OH), $1594(\mathrm{Ph} \mathrm{C}=\mathrm{C}) \mathrm{cm}^{-1}$. EI-MS (m/z): 331 (M), 243 (Trt), 165 (Trt-PhH). ${ }^{1} \mathrm{H}$ NMR: $\delta$ $4.900\left(2 \mathrm{H}\right.$, br. s, $\left.\mathrm{NH}, \mathrm{CO}_{2} \mathrm{H}\right), 2.506\left(2 \mathrm{H}, \mathrm{t}, J=5.2 \mathrm{~Hz}, \mathrm{NCH}_{2}\right), 2.451\left(2 \mathrm{H}, \mathrm{t}, J=5.2 \mathrm{~Hz}, \mathrm{CH}_{2} \mathrm{CO}\right)$. ${ }^{13} \mathrm{C}$ NMR: $\delta 176.736\left(\mathrm{CO}_{2} \mathrm{H}\right), 71.866\left(\mathrm{Ph}_{3} \mathrm{C}\right), 39.785\left(\mathrm{NCH}_{2}\right), 35.061\left(\mathrm{CH}_{2} \mathrm{CO}_{2} \mathrm{H}\right)$. Anal. Calcd for $\mathrm{C}_{22} \mathrm{H}_{21} \mathrm{NO}_{2}$ (331.42): C, 79.73; H, 6.39; N, 4.23. Found: C, 79.93; H, 6.11; N, 4.05.

2,5-Dioxopyrrolidin-1-yl $\boldsymbol{N}$-trityl- $\beta$-alaninate (5). To an ice-cold suspension of Trt- $\beta$ Ala $(24.4 \mathrm{~g}, 73.6 \mathrm{mmol})$ in THF $(150 \mathrm{~mL})$ and DMF $(50 \mathrm{~mL})$ was added HOSu $(10.2 \mathrm{~g}, 88.3 \mathrm{mmol})$ and subsequently after $10 \mathrm{~min}$ DCC $(16.7 \mathrm{~g}, 81 \mathrm{mmol})$. The resulting reaction mixture was stirred at $0{ }^{\circ} \mathrm{C}$ for $1 \mathrm{~h}$ and then at ambient temperature overnight. The precipitated $N, N^{\prime}-$ dicyclohexylurea (DCU) was filtered off, and the residue on the filter was washed with hot THF. The filtrate was evaporated under reduced pressure, and the residue was taken up in EtOAc $(300 \mathrm{~mL})$ and washed twice with an ice-cold saturated aqueous $\mathrm{NaCl}$ solution (brine). Drying, evaporation to one third of the volume and refrigeration overnight gave crystalline product SAE 5 (26.8 g, 85\%), mp 178-80 ${ }^{\circ} \mathrm{C}$; $\mathrm{R}_{\mathrm{f}}$ (E) 0.63. FT-IR: 3326 ( $\mathrm{NH}$-Trt), 1818 and 1782 (CO-OSu), $1746(\mathrm{~N}-\mathrm{CO})) \mathrm{cm}^{-1}$. LSI-MS (m/z): $451(M \mathrm{Na}), 429(\mathrm{MH}), 351(\mathrm{MH}-\mathrm{PhH}), 243$ (Trt), 165 (TrtPhH). ${ }^{1} \mathrm{H}$ NMR: $\delta 2.788\left(6 \mathrm{H}, \mathrm{m}, \mathrm{H}-2\right.$ and $\left.\mathrm{CO}\left(\mathrm{CH}_{2}\right)_{2} \mathrm{CO}\right), 2.518(2 \mathrm{H}, \mathrm{t}, J=6.4 \mathrm{~Hz}, \mathrm{H}-3), 2.083$ (1H, br. s, NH). ${ }^{13} \mathrm{C}$ NMR: $\delta 169.452\left(\mathrm{COCH}_{2}\right), 168.302(\mathrm{C}-1), 71.367\left(\mathrm{Ph}_{3} \mathrm{C}\right), 39.496(\mathrm{C}-3)$, 32.947 (C-2), $25.982\left(\mathrm{COCH}_{2}\right)$. Anal. Calcd for $\mathrm{C}_{26} \mathrm{H}_{24} \mathrm{~N}_{2} \mathrm{O}_{4}$ (428.49): C, 72.88; H, 5.65; N, 6.54. Found: C, 73.03; H, 5.75; N, 6.24 .

$\boldsymbol{N}$-Trityl- $\beta$-alanyl- $\boldsymbol{\gamma}$-aminobutyric acid (8). To a magnetically stirred suspension of $\gamma \mathrm{Aba}(6.6 \mathrm{~g}$, $64 \mathrm{mmol})$ in anhydrous $\mathrm{CH}_{2} \mathrm{Cl}_{2}(90 \mathrm{~mL})$ was added $\mathrm{Me}_{3} \mathrm{SiCl}(8.9 \mathrm{~mL}, 70.4 \mathrm{mmol})$, and the reaction mixture was stirred at ambient temperature for $10 \mathrm{~min}$. The resulting solution was icecooled and then treated with SAE $5(24.9 \mathrm{~g}, 58 \mathrm{mmol})$ followed by the dropwise addition of anhydrous $\mathrm{Et}_{3} \mathrm{~N}(16 \mathrm{ml}, 115 \mathrm{mmol})$ within $30 \mathrm{~min}$. Stirring was continued at $0{ }^{\circ} \mathrm{C}$ for $15 \mathrm{~min}$ and at ambient temperature for $15 \mathrm{~min}$. $\mathrm{MeOH}(5 \mathrm{~mL})$ was introduced, the resulting reaction mixture 
was diluted with $\mathrm{CH}_{2} \mathrm{Cl}_{2}(300 \mathrm{~mL})$ and then washed once with an ice-cold $5 \%$ aqueous citric acid solution and twice with $\mathrm{H}_{2} \mathrm{O}$. Drying and evaporation to dryness left a residue which, upon dissolution in a minimum volume of hot EtOAc and overnight refrigeration gave crystalline dipeptide acid $8(19.1 \mathrm{~g}, 79 \%)$, mp $157-59^{\circ} \mathrm{C} ; \mathrm{R}_{\mathrm{f}}(\mathrm{G})$ 0.16. FT-IR: 3300-2500 (OH), $3298(\mathrm{NH})$, 1712 (CO-OH), 1634 (NH-CO)) cm ${ }^{-1}$. EI-MS (m/z): 417 (MH), 339 (MH-PhH), 243 (Trt), 165 (Trt-PhH). ${ }^{1} \mathrm{H}$ NMR (DMSO- $\left.d_{6}\right): \delta 7.848(1 \mathrm{H}$, unresolved t, H-5), $3.024(2 \mathrm{H}, \mathrm{q}, J=6.0 \mathrm{~Hz}, \mathrm{H}-$ 4), 2.247 (2H, t, $J=6.4 \mathrm{~Hz}, \mathrm{H}-8), 2.200(2 \mathrm{H}, \mathrm{t}, J=7.2 \mathrm{~Hz}, \mathrm{H}-2), 2.145$ (2H, t, $J=6.4 \mathrm{~Hz}, \mathrm{H}-7$ ), $1.600(2 \mathrm{H}$, quintet, $J=7.2 \mathrm{~Hz}, \mathrm{H}-3) .{ }^{13} \mathrm{C}$ NMR: $\delta 175.082(\mathrm{C}-1), 172.263(\mathrm{C}-6), 71.127\left(\mathrm{Ph}_{3} \mathrm{C}\right)$, 40.342 (C-4), 38.664 (C-8), 36.995 (C-2), 31.944 (C-7), 24.869 (C-3). Anal. Calcd for $\mathrm{C}_{26} \mathrm{H}_{28} \mathrm{~N}_{2} \mathrm{O}_{3}$ (416.52): C, 74.98; H, 6.78; N, 6.72. Found: C, 75.14; H, 6.50; N, 6.44.

Succinimidyl $\boldsymbol{N}$-trityl- $\beta$-alanyl- $\boldsymbol{\gamma}$-aminobutyrate (6). To an ice-cold suspension of Trt- $\beta$ Ala$\gamma$ Aba $(19.6 \mathrm{~g}, 47 \mathrm{mmol})$ in THF $(110 \mathrm{~mL})$ and DMF $(40 \mathrm{~mL})$ was added HOSu $(6.1 \mathrm{~g}, 53 \mathrm{mmol})$ followed after $10 \mathrm{~min}$ by DCC $(10.5 \mathrm{~g}, 51 \mathrm{mmol})$. The resulting reaction mixture was stirred at $0{ }^{\circ} \mathrm{C}$ for $1 \mathrm{~h}$ and then at ambient temperature overnight. The precipitated DCU was filtered off and washed on the filter with hot THF. The filtrate was evaporated under reduced pressure, and the residue was taken up in EtOAc $(200 \mathrm{~mL})$ and washed twice with ice-cold brine. Drying, evaporation to dryness, dissolution of the oily residue in $\mathrm{CH}_{2} \mathrm{Cl}_{2}$, overnight refrigeration and filtration removed an additional amount of DCU. Evaporation of $\mathrm{CH}_{2} \mathrm{Cl}_{2}$ and addition of $\mathrm{Et}_{2} \mathrm{O}$ followed by overnight refrigeration gave the crystalline product SAE $6(21.2 \mathrm{~g}, 88 \%)$, mp 101-04 ${ }^{\circ} \mathrm{C}$; $\mathrm{R}_{\mathrm{f}}(\mathrm{E})$ 0.57. FT-IR: 3326 and $3296(\mathrm{NH}), 1816$ and $1788(\mathrm{CO}-\mathrm{OSu}), 1740(\mathrm{~N}-\mathrm{CO})$ and 1630 $(\mathrm{NH}-\mathrm{CO}) \mathrm{cm}^{-1}$. LSI-MS (m/z): $536(\mathrm{MNa}), 514(\mathrm{MH}), 436(\mathrm{MH}-\mathrm{PhH}), 339\left[\mathrm{MH}-\mathrm{N}\left(\mathrm{COCH}_{2}\right)_{2}{ }^{-}\right.$ Ph], 243 (Trt), 165 (Trt-PhH). ${ }^{1} \mathrm{H}$ NMR: $\delta 6.720(1 \mathrm{H}$, unresolved t, H-5), 3.363 (2H, q, $J=6.4$ $\mathrm{Hz}, \mathrm{H}-4), 2.790\left(4 \mathrm{H}\right.$, br. s, $\left.\mathrm{CO}\left(\mathrm{CH}_{2}\right)_{2} \mathrm{CO}\right), 2.638(2 \mathrm{H}, \mathrm{t}, J=6.8 \mathrm{~Hz}, \mathrm{H}-2), 2.473(2 \mathrm{H}, \mathrm{t}, J=5.6$ $\mathrm{Hz}, \mathrm{H}-8), 2.372(2 \mathrm{H}, \mathrm{t}, J=5.6 \mathrm{~Hz}, \mathrm{H}-7), 1.980(2 \mathrm{H}$, quintet, $J=6.8 \mathrm{~Hz}, \mathrm{H}-8) .{ }^{13} \mathrm{C}$ NMR: $\delta$ 172.268 (C-6), $169.627\left(\mathrm{CO}\left(\mathrm{CH}_{2}\right)_{2} \mathrm{CO}\right), 168.767(\mathrm{C}-1), 71.558\left(\mathrm{Ph}_{3} \mathrm{C}\right), 46.342(\mathrm{C}-4), 38.646(\mathrm{C}-$ 8), 37.057 (C-2), 29.062 (C-7), $26.448\left(\mathrm{CO}\left(\mathrm{CH}_{2}\right)_{2} \mathrm{CO}\right), 25.927$ (C-3). Anal. Calcd for $\mathrm{C}_{30} \mathrm{H}_{31} \mathrm{~N}_{3} \mathrm{O}_{5}$ (513.59): C, 70.16; H, 6.08; N, 8.18. Found: C, 69.93; H, 6.30; N, 8.29.

$1 N, 12 N$-Bis(tritylamino)-4,9-diazadodecane-3,10-dione (9a). To a magnetically stirred solution of SAE $5(25.71 \mathrm{~g}, 60 \mathrm{mmol})$ in DMF $(230 \mathrm{~mL})$ was added PUT $(2.64 \mathrm{~g}, 30 \mathrm{mmol})$. After 15 min at ambient temperature, the $\mathrm{pH}$ of the reaction mixture was adjusted to 8 by the addition of $\mathrm{Et}_{3} \mathrm{~N}$, followed by stirring at for $24 \mathrm{~h}$. The reaction mixture was then diluted with $\mathrm{H}_{2} \mathrm{O}(600 \mathrm{~mL})$, and the precipitated product was extracted with $\mathrm{CH}_{2} \mathrm{Cl}_{2}$. The organic phase was washed sequentially once with $\mathrm{H}_{2} \mathrm{O}$, twice with a $5 \%$ aqueous $\mathrm{NaHCO}_{3}$ solution and finally twice with $\mathrm{H}_{2} \mathrm{O}$, dried and evaporated to a volume that induced crystallization. Refrigeration, filtration of the precipitated solid and washing on the filter initially with ice-cold $\mathrm{CH}_{2} \mathrm{Cl}_{2}$ followed by $\mathrm{Et}_{2} \mathrm{O}$ and hexane gave pure bisamide 9a $(19.3 \mathrm{~g}, 90 \%), \mathrm{mp} 182-85^{\circ} \mathrm{C} ; \mathrm{R}_{\mathrm{f}}(\mathrm{G}) 0.68$. FT-IR: 3328 and $3277(\mathrm{NH}), 1634$ (NH-CO) cm ${ }^{-1}$. FAB-MS (m/z): $716(M H), 473(M-T r t), 395$ (M-Trt-PhH), 243 (Trt). ${ }^{1} \mathrm{H}$ NMR: $\delta 6.503$ (2H, unresolved t, H-4 and H-9), 3.371 (4H, q, $J=5.6$ $\mathrm{Hz}, \mathrm{H}-5$ and $\mathrm{H}-8), 2.434(4 \mathrm{H}, \mathrm{t}, J=6.0 \mathrm{~Hz}, \mathrm{H}-1$ and $\mathrm{H}-12), 2.295(4 \mathrm{H}, \mathrm{t}, J=6.0 \mathrm{~Hz}, \mathrm{H}-2$ and $\mathrm{H}-$ 11), 1.546 (4H, m, H-6, H-7). ${ }^{13} \mathrm{C}$ NMR: $\delta 172.782$ (C-3 and C-10), $71.381\left(\mathrm{Ph}_{3} \mathrm{C}\right), 40.334(\mathrm{C}-5$ 
and C-8), 39.377 (C-1 and C-12), 37.526 (C-2 and C-11), 27.417 (C-6 and C-7). Anal. Calcd for $\mathrm{C}_{48} \mathrm{H}_{50} \mathrm{~N}_{4} \mathrm{O}_{2}$ (714.96): C, 80.64; H, 7.05; N, 7.84. Found: C, 80.84; H, 6.87; N, 7.60.

1N,12N-Bis[3-(tritylamino)propyl]butane-1,4-diamine (10a). To a magnetically stirred suspension of $\mathrm{LiAlH}_{4}(6.4 \mathrm{~g}, 168 \mathrm{mmol})$ in anhydrous THF $(220 \mathrm{~mL})$ at reflux temperature was added bisamide 9a $(20 \mathrm{~g}, 28 \mathrm{mmol})$ in $c a$. equal portions within $30 \mathrm{~min}$, and refluxing was continued for $4 \mathrm{~d}$. The resulting reaction mixture was ice-cooled, and excess $\mathrm{LiAlH}_{4}$ was carefully quenched by dropwise addition of a saturated aqueous $\mathrm{Na}_{2} \mathrm{SO}_{4}$ solution. The resulting salts were filtered off by vacuum filtration and washed on the filter with distilled THF. The filtrate was concentrated to dryness, and the resulting oily residue was dissolved in EtOAc and washed twice with brine. Drying and evaporation gave an oily residue which upon trituration with $\mathrm{Et}_{2} \mathrm{O}$ and refrigeration gave $\mathrm{SPM}$ derivative 10a $(13 \mathrm{~g}, 68 \%)$. This product was recrystallized from $\mathrm{MeOH}(700 \mathrm{~mL}), \mathrm{mp} 116-17^{\circ} \mathrm{C}$; $\mathrm{R}_{\mathrm{f}}(\mathrm{M})$ 0.78. FT-IR: $3268(\mathrm{NH}) \mathrm{cm}^{-1}$. FABMS (m/z): 688 (MH), 609 (M-PhH), 445 (M-Trt), 367 (M-Trt-PhH), 243 (Trt). HR-MS: Found 687.4441 $\left(\mathrm{M}^{+}+1\right), \mathrm{C}_{48} \mathrm{H}_{55} \mathrm{~N}_{4}$ requires $\mathrm{M}^{+}+1=687.4427 .{ }^{1} \mathrm{H} \mathrm{NMR}: \delta 2.656(4 \mathrm{H}, \mathrm{t}, J=7.2 \mathrm{~Hz}, \mathrm{H}-1$ and $\mathrm{H}-12$ ), 2.580 (4H, unresolved $\mathrm{t}, \mathrm{H}-3$ and $\mathrm{H}-10), 2.184$ (4H, unresolved $\mathrm{t}, \mathrm{H}-5$ and $\mathrm{H}-8$ ), 1.752 (2H, br. s, H-4 and H-9), 1.650 (4H, quintet, $J=6.8 \mathrm{~Hz}, \mathrm{H}-2$ and H-11), 1.475 (4H, unresolved quintet, H-6 and H-7). ${ }^{13} \mathrm{C}$ NMR: $\delta 71.320\left(\mathrm{Ph}_{3} \mathrm{C}\right), 50.440(\mathrm{C}-1$ and $\mathrm{C}-12), 48.966$ (C-3 and C-10), 42.528 (C-5 and C-8), 31.498 (C-2 and C-11), 28.499 (C-6 and C-7) . Anal. Calcd for $\mathrm{C}_{48} \mathrm{H}_{54} \mathrm{~N}_{4}$ (686.99): C, 83.92; H, 7.92; N, 8.16. Found: C, 83.71; H, 8.05; N, 8.30.

$1 \mathrm{~N}, 16 \mathrm{~N}$-Bis(tritylamino)-4,13-diazahexadecane-3,14-dione (9b). To a magnetically stirred ice-cold solution of DAO $(0.72 \mathrm{~g}, 5 \mathrm{mmol})$ in dry DMF $(8 \mathrm{~mL})$ was added anhydrous $\mathrm{Et}_{3} \mathrm{~N}(1.4$ $\mathrm{mL}, 10 \mathrm{mmol})$, followed by SAE $5(4.46 \mathrm{~g}, 10.4 \mathrm{mmol})$. The reaction mixture was stirred at $0{ }^{\circ} \mathrm{C}$ for $30 \mathrm{~min}$ and then at ambient temperature overnight.. It was then diluted with $\mathrm{CHCl}_{3}$ and washed sequentially twice with a $5 \%$ aqueous $\mathrm{NaHCO}_{3}$ solution and thrdee times with $\mathrm{H}_{2} \mathrm{O}$, dried, evaporated, and the residue was triturated with $\mathrm{Et}_{2} \mathrm{O}$. Overnight refrigeration gave pure bisamide 9b (3 g, 78\%), mp 158-59 ${ }^{\circ} \mathrm{C}$; $\mathrm{R}_{\mathrm{f}}(\mathrm{E})$ 0.43. FT-IR: $3290(\mathrm{NH}), 1629(\mathrm{NHCO}) \mathrm{cm}^{-1}$. ESIMS (m/z): $772.13(M H) . ~{ }^{1} \mathrm{H}$ NMR: $\delta 6.332(2 \mathrm{H}, \mathrm{t}, J 5.20 \mathrm{~Hz}, \mathrm{H}-4$ and H-9), 3.210 (4H, t, $J=6.4$ Hz, H-5 and H-8), 2.446 (4H, t, $J=6.0 \mathrm{~Hz}, \mathrm{H}-1$ and H-12), 2.311 (4H, t, $J=6.0 \mathrm{~Hz}, \mathrm{H}-2$ and H11), 1.487 (4H, quintet, $J=6.8$ Hz, H-6 and H-7), 1.284 (8H, br. s, H-6', H-7', H-6" and H-7"). ${ }^{13} \mathrm{C}$ NMR: $\delta 172.454$ (C-3 and C-10), $71.437\left(\mathrm{Ph}_{3} \mathrm{C}\right), 40.362$ (C-5 and C-8), 39.789 (C-1 and C12), 37.638 (C-2 and C-11), 30.046 (C-6 and C-7), 29.520 (C-6' and C-7'), 27.277 (C-6" and C7"). Anal. Calcd for $\mathrm{C}_{52} \mathrm{H}_{58} \mathrm{~N}_{4} \mathrm{O}_{2}$ (771.06): C, 81.00; H, 7.58; N, 7.27. Found: C, 81.20; H, 7.32; $\mathrm{N}, 7.15$.

1N,16N-Bis[3-(tritylamino)propyl]octane-1,8-diamine (10b). Bisamide 9b (1.55 g, $2 \mathrm{mmol})$ was treated with $\mathrm{LiAlH}_{4}(0.46 \mathrm{~g}, 12 \mathrm{mmol})$ in anhydrous THF $(25 \mathrm{~mL})$ for $2 \mathrm{~d}$ as described for 9a. Following identical work-up procedure followed by FCC purification using the solvent system I as eluant,. pure tetra-amine $10 \mathrm{~b}$ was obtained as an oil $(0.9 \mathrm{~g}, 67 \%), \mathrm{R}_{\mathrm{f}}(\mathrm{I})$ 0.5. ESI-MS $(\mathrm{m} / \mathrm{z}): 743.05(M \mathrm{H}), 501.39$ (MH-Trt), 243 (Trt). HR-MS (m/z): Found $743.5053\left(\mathrm{M}^{+}+1\right)$, $\mathrm{C}_{52} \mathrm{H}_{63} \mathrm{~N}_{4}$ requires $\mathrm{M}^{+}+1=743.5056 .{ }^{1} \mathrm{H}$ NMR: $\delta 2.741(4 \mathrm{H}, \mathrm{t}, J=7.2 \mathrm{~Hz}, \mathrm{H}-3$ and H-10), 2.627 $(4 \mathrm{H}, \mathrm{t}, J=7.2 \mathrm{~Hz}, \mathrm{H}-1$ and H-12), 2.204 (4H, t, $J=6.8 \mathrm{~Hz}, \mathrm{H}-5$ and H-8), 1.734 (4H, quintet, $J=$ 
$6.0 \mathrm{~Hz}, \mathrm{H}-2$ and $\mathrm{H}-11), 1.517(4 \mathrm{H}$, quintet, $J=6.8 \mathrm{~Hz}, \mathrm{H}-6$ and $\mathrm{H}-7), 1.299(8 \mathrm{H}, \mathrm{m},(\mathrm{C}-$ $\left.6^{\prime}, 7^{\prime}, 6^{\prime \prime}, 7^{\prime \prime}\right) .{ }^{13} \mathrm{C}$ NMR: $\delta 71.338\left(\mathrm{Ph}_{3} \mathrm{C}\right), 50.287$ (C-3 and C-10), 48.898 (C-1 and C-12), 42.449 (C-5 and C-8), 30.584 (C-2 and C-11), 29.815 (C-6 and C-7), 29.449 (C-6',7'), 27.388 (6", $\left.7^{\prime \prime}\right)$. Anal. Calcd for $\mathrm{C}_{52} \mathrm{H}_{62} \mathrm{~N}_{4}$ (743.09): C, 84.05; H, 8.41; N, 7.54. Found: C, 84.20; H, 8.15; N, 7.41 .

$1 N, 22 N$-Bis(tritylamino)-1,4,9,14,19,22-hexaazadocosane-3,8,15,20-tetraone (11). To a magnetically stirred ice-cold solution of PUT $(0.32 \mathrm{~g}, 3.6 \mathrm{mmol})$ in dry DMF $(10 \mathrm{~mL})$ was added anhydrous $\mathrm{Et}_{3} \mathrm{~N}(1 \mathrm{~mL}, 7.2 \mathrm{mmol})$, followed by SAE $6(3.7 \mathrm{~g}, 7.2 \mathrm{mmol})$. The reaction mixture was stirred at $0{ }^{\circ} \mathrm{C}$ for $30 \mathrm{~min}$ and then at ambient temperature overnight.. It was then diluted with $\mathrm{CHCl}_{3}$ and washed sequentially with a $5 \%$ aqueous $\mathrm{NaHCO}_{3}$ solution (twice) and with $\mathrm{H}_{2} \mathrm{O}$ (three times), dried, evaporated to a volume that induced crystallization. Overnight refrigeration gave pure tetra-amide $11(2.61 \mathrm{~g}, 82 \%)$, mp $185-86^{\circ} \mathrm{C}$; $\mathrm{R}_{\mathrm{f}}(\mathrm{E})$ 0.32. FT-IR: $3290(\mathrm{NH}), 1635(\mathrm{NHCO})$ $\mathrm{cm}^{-1}$. ESI-MS (m/z): $886.41(\mathrm{MH}), 243.12$ (Trt). Anal. Calcd for $\mathrm{C}_{56} \mathrm{H}_{64} \mathrm{~N}_{6} \mathrm{O}_{4}$ (885.17): C, 75.99; H, 7.29; N, 9.49. Found: C, 75.80; H, 7.49; N, 9.67. $N^{4}, N^{9}, N^{14}, N^{19}$-Tetra(tert-butoxycarbonyl)- $N^{1}, N^{22}$-ditrityl-1,22-diamino-4,9,14,19-tetraazadocosane (13). Tetra-amide 11 (1.28 g, $1.45 \mathrm{mmol})$ was treated with $\mathrm{LiAlH}_{4}(0.55 \mathrm{~g}, 14.5 \mathrm{mmol})$ in anhydrous THF $(10 \mathrm{~mL})$ for $4 \mathrm{~d}$ as described for 9a. Identical work-up afforded the crude product 12 as an oil, $\mathrm{R}_{\mathrm{f}}(\mathrm{O}) 0.16$. To a solution of this product in anhydrous $\mathrm{CHCl}_{3}(4 \mathrm{~mL})$ were added dry Et $3 \mathrm{~N}(1 \mathrm{~mL}, 7.25 \mathrm{mmol})$ and DMAP $(0.1 \mathrm{~g}, 0.8 \mathrm{mmol})$, the mixture was cooled to $0{ }^{\circ} \mathrm{C}$ and treated with $\mathrm{Boc}_{2} \mathrm{O}(1.58 \mathrm{~g}, 7.25 \mathrm{mmol})$ for $30 \mathrm{~min}$ at this temperature and at ambient temperature overnight. The resulting solution was diluted with more $\mathrm{CHCl}_{3}$ and washed sequentially with a $5 \%$ aqueous $\mathrm{NaHCO}_{3}$ solution and with $\mathrm{H}_{2} \mathrm{O}$ (twice), dried and evaporated to leave a residue. From this residue upon FCC purification using solvent system B as eluant pure product $13(0.54 \mathrm{~g}, 30 \%)$ was obtained as a white foam, $\mathrm{R}_{\mathrm{f}}(\mathrm{B})$ 0.37. ESI-MS $(\mathrm{m} / \mathrm{z}): 1,229.82$ $(M), 987.81(M-T r t), 243$ (Trt). $\mathrm{C}_{76} \mathrm{H}_{104} \mathrm{~N}_{6} \mathrm{O}_{8}$ requires $\mathrm{M}^{+}=1,229.70$.

4,9,14,19-Tetraazadocosane-1,22-diamine (14). A solution of the protected hexa-amine 13 $(0.39 \mathrm{~g}, 0.32 \mathrm{mmol})$ in $\mathrm{CH}_{2} \mathrm{Cl}_{2} / \mathrm{TFA}(1: 1,4 \mathrm{~mL})$ was kept at ambient temperature for $30 \mathrm{~min}$. Evaporation to dryness, trituration with $\mathrm{Et}_{2} \mathrm{O}$ and overnight refrigeration gave the hexa(trifluoroacetate) salt of hexa-amine $14(0.25 \mathrm{~g}, 75 \%)$ as an oil. HR-MS: Found 345.3715 $\left(\mathrm{M}^{+}+1\right), \mathrm{C}_{18} \mathrm{H}_{45} \mathrm{~N}_{6}$ requires $\mathrm{M}^{+}+1=345.3706$.

\section{2-(10'-Tritylamino-3', $\mathbf{8}^{\prime}$-dioxo-2', $7^{\prime}$-diazadecyl)-1,4,7,10,13,16-hexaoxacyclohexadecane}

(15). To a magnetically stirred solution of commercial crown ether $5(1 \mathrm{~g}, 3.41 \mathrm{mmol})$ in anhydrous DMF $(4 \mathrm{~mL})$ at ambient temperature were added sequentially $\operatorname{dry} \mathrm{Et}_{3} \mathrm{~N}(0.5 \mathrm{~mL}$, $3.6 \mathrm{mmol})$ and SAE $6(1.75 \mathrm{~g}, 3.41 \mathrm{mmol})$. After an additional $1 \mathrm{~h}$ the reaction mixture was diluted with $\mathrm{CHCl}_{3}$ and washed sequentially with a $5 \%$ aqueous $\mathrm{NaHCO}_{3}$ solution and with brine (twice). Drying and evaporation to dryness furnished a residue from which upon FCC purification with solvent system $\mathrm{G}$ as eluant bisamide $15(1.56 \mathrm{~g}, 66 \%)$ was obtained as an oil, $\mathrm{R}_{\mathrm{f}}(\mathrm{G})$ 0.08. ESI-MS (m/z): 731,35 (MK), $715.08(M \mathrm{Na}), 693.02(M \mathrm{H}), 243.11(\mathrm{Trt}) . \mathrm{C}_{39} \mathrm{H}_{53} \mathrm{~N}_{3} \mathrm{O}_{8}$ requires $\mathrm{M}^{+}=691.83$. 
2-(10'-Tritylamino-2',7'-diazadecyl)-1,4,7,10,13,16-hexaoxacyclohexadecane (16). A solution of bisamide 15 (1.56 g, $2.25 \mathrm{mmol})$ in anhydrous THF $(13 \mathrm{~mL})$ was added dropwise within $45 \mathrm{~min}$ to a magnetically stirred suspension of $\mathrm{LiAlH}_{4}(0.44 \mathrm{~g}, 13.5 \mathrm{mmol})$ in refluxing THF $(5 \mathrm{~mL})$. The reaction mixture was stirred at this temperature overnight and was worked-up as described for the preparation of $\mathbf{1 0 a}$. From the resulting crude reaction product upon FCC purification using the solvent system $\mathrm{L}$ as eluant pure product $16(0.66 \mathrm{~g}, 45 \%)$ was obtained as an oil, $\mathrm{R}_{\mathrm{f}}(\mathrm{N})$ 0.21. ESI-MS (m/z): $687(\mathrm{MNa}), 665(\mathrm{MH}), 422(\mathrm{MH}-\mathrm{Trt}), 243$ (Trt). $\mathrm{C}_{39} \mathrm{H}_{57} \mathrm{~N}_{3} \mathrm{O}_{6}$ requires $\mathrm{M}^{+}=663.90 .{ }^{1} \mathrm{H}$ NMR: $\delta 3.907(1 \mathrm{H}$, ddd, $\mathrm{J}=6.6,4.4$ and $3.6 \mathrm{~Hz}, \mathrm{CH}-\mathrm{O}), 3.678(22 \mathrm{H}$, m, $\left.\mathrm{CH}_{2}-\mathrm{O}\right), 2.695$ (4H, m, H-1' and H-3'), 2.614 (4H, m, H-6 ' and H-8'), 2.179 (2H, t, $J=6.8 \mathrm{~Hz}$, H-10'), 2.054 (3H, br. s, NH), 1.687 (2H, t, $J=6.4$ Hz, H-9'), 1.520 (4H, m, H-4' and H-5') . ${ }^{13} \mathrm{C}$ NMR: $\delta 78.880(\mathrm{CH}-\mathrm{O}), 71.337\left(\mathrm{Ph}_{3} \mathrm{C}\right), 73.395,71.251-70.959$ and $70.187\left(11 \mathrm{C}, \mathrm{CH}_{2}-\mathrm{O}\right)$, $51.466\left(\mathrm{C}-1^{\prime}\right), 50.298$ and $50.255\left(\mathrm{C}-6^{\prime}\right.$ and $\left.\mathrm{C}-8^{\prime}\right), 48.786\left(\mathrm{C}-3^{\prime}\right), 42.490\left(\mathrm{C}-10^{\prime}\right), 31.287\left(\mathrm{C}-9^{\prime}\right)$, $28.307\left(\mathrm{C}-4^{\prime}\right.$ and $\left.\mathrm{C}-5^{\prime}\right)$.

2-(10'-Amino-2',7'-diazadecyl)-1,4,7,10,13,16-hexaoxacyclohexadecane (17). A solution of tritylated triamine $16(0.45 \mathrm{~g}, 0.68 \mathrm{mmol})$ in $6 \mathrm{~mL}$ of $\mathrm{CH}_{2} \mathrm{Cl}_{2} / \mathrm{TFA}(1: 1)$ was kept at ambient temperature for $1 \mathrm{~h}$. Evaporation to dryness, trituration with $\mathrm{Et}_{2} \mathrm{O}$ and refrigeration for several days gave pure triamine 17 as tristrifluoroacetate salt $(0.38 \mathrm{~g}, 73 \%), \mathrm{mp} 136-40{ }^{\circ} \mathrm{C} ; \mathrm{R}_{\mathrm{f}}(\mathrm{N}) 0.06$. HR-MS (m/z): Found $422.2647\left(\mathrm{M}^{+}+1\right), \mathrm{C}_{20} \mathrm{H}_{44} \mathrm{~N}_{3} \mathrm{O}_{6}$ requires $\mathrm{M}^{+}+1=422.2656$.

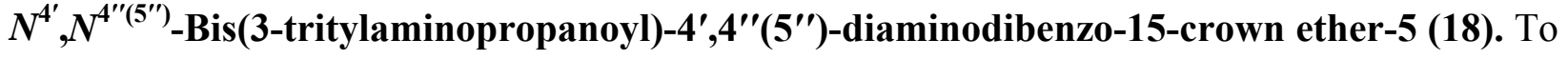
a magnetically stirred suspension of crown ether 6 (1 g, 2.89 mmol) in anhydrous DMF (6 mL) $i \operatorname{Pr}_{2} \mathrm{NEt}(1 \mathrm{~mL}, 6 \mathrm{mmol})$ and SAE $5(2.49 \mathrm{~g}, 5.8 \mathrm{mmol})$ were added sequentially, and the resulting reaction mixture was kept at $60{ }^{\circ} \mathrm{C}$ for $2 \mathrm{~h}$. It was then treated with an additional quantity of SAE $5(0.43 \mathrm{~g}, 1 \mathrm{mmol})$ for a further $1 \mathrm{~h}$ at that temperature and for overnight at ambient temperature. The reaction mixture was diluted with $\mathrm{CHCl}_{3}$ and washed sequentially with a $5 \%$ aqueous $\mathrm{K}_{2} \mathrm{CO}_{3}$ solution (twice) and with $\mathrm{H}_{2} \mathrm{O}$, dried $\left(\mathrm{MgSO}_{4}\right)$ and evaporated to leave a residue. Upon FCC purification using EtOAc as eluant pure 18 (1.55 g, 55\%) was obtained as a beige foam, $\mathrm{R}_{\mathrm{f}}(\mathrm{E})$ 0.27. ESI-MS $(\mathrm{m} / \mathrm{z}): 996 \quad(\mathrm{MNa}), 316 \quad\left[\operatorname{TrtNH}\left(\mathrm{CH}_{2}\right)_{2} \mathrm{CHO}+\mathrm{H}\right], 288$ ( $\operatorname{TrtNHCH} \mathrm{CH}_{3}+\mathrm{H}$ ), 243 (Trt). $\mathrm{C}_{62} \mathrm{H}_{60} \mathrm{~N}_{4} \mathrm{O}_{7}$ requires $\mathrm{M}^{+}=973.18$.

$N^{4^{\prime}}, N^{4^{\prime \prime}\left(5^{\prime \prime}\right)}$-Bis(3-tritylaminopropyl)-4', $4^{\prime \prime}\left(5^{\prime \prime}\right)$-diaminodibenzo-15-crown ether-5 (19). Bisamide 18 (1.5 g, $1.54 \mathrm{mmol})$ was added portionwise within $30 \mathrm{~min}$ to a magnetically stirred suspension of $\mathrm{LiAlH}_{4}(0.3 \mathrm{~g}, 9 \mathrm{mmol})$ in refluxing THF $(10 \mathrm{~mL})$. The reaction mixture was stirred at this temperature for $2 \mathrm{~d}$. Excess hydride was destroyed at $-10^{\circ} \mathrm{C}$ ' by the dropwise addition of a saturated aqueous $\mathrm{K}_{2} \mathrm{SO}_{4}$ solution. Filtration, washing with distilled THF, and finally evaporation of the filtrates left a residue. This was taken-up in EtOAc and washed twice with the above mentioned $\mathrm{K}_{2} \mathrm{SO}_{4}$ solution, dried $\left(\mathrm{MgSO}_{4}\right)$ and evaporated to dryness. FCC purification using initially solvent system $\mathrm{C}$ followed by solvent system $\mathrm{D}$ gave pure product 19 $(1.19 \mathrm{~g}, 82 \%)$ as an oil, $\mathrm{R}_{\mathrm{f}}(\mathrm{C})$ 0.25. ESI-MS (m/z): $946(M H), 258(\operatorname{TrtNH}), 243$ (Trt). $\mathrm{C}_{62} \mathrm{H}_{64} \mathrm{~N}_{4} \mathrm{O}_{5}$ requires $\mathrm{M}^{+}=945.11 .{ }^{1} \mathrm{H}$ NMR: $\delta 6.819\left(2 \mathrm{H}, \mathrm{d}, J=8.8 \mathrm{~Hz}, \mathrm{H}-4{ }^{\prime \prime}\right), 6.219(2 \mathrm{H}$, unresolved d, H-1"), 6.143 (2H, dd, $J=8.8$ and $\left.2.4 \mathrm{~Hz}, \mathrm{H}-3^{\prime \prime}\right), 4.26-4.25$ (4H, m, H-5 and H-6), $4.128(4 \mathrm{H}, \mathrm{t}, J=4.0 \mathrm{~Hz}, \mathrm{H}-1$ and H-4), 3.919 (4H, t, $J=4.4 \mathrm{~Hz}, \mathrm{H}-2$ and H-3), 3.163 (4H, t, $J=$ 
$\left.6.4 \mathrm{~Hz}, \mathrm{H}-\mathrm{1}^{\prime}\right), 2.270\left(4 \mathrm{H}, \mathrm{t}, J=6.0 \mathrm{~Hz}, \mathrm{H}-3^{\prime}\right), 1.755\left(4 \mathrm{H}\right.$, quintet, $\left.J=6.0 \mathrm{~Hz}, \mathrm{H}-2^{\prime}\right) .{ }^{13} \mathrm{C}$ NMR: $\delta$ $151.311\left(\mathrm{C}-6^{\prime \prime}\right), 144.896\left(\mathrm{C}-5^{\prime \prime}\right), 142.095\left(\mathrm{C}-2^{\prime \prime}\right), 102.564\left(\mathrm{C}-1^{\prime \prime}\right), 105.542\left(\mathrm{C}-3^{\prime \prime}\right), 119.113(\mathrm{C}-$ 4"), $71.511\left(\mathrm{Ph}_{3} \mathrm{C}\right), 70.873$ (C-5 and $\left.\mathrm{C}-6\right), 70.298$ and 70.255 (4C, $\left.\mathrm{C}-1 / 2 / 3 / 4\right), 43.648\left(\mathrm{C}-1^{\prime}\right)$, $42.280\left(\mathrm{C}-3^{\prime}\right), 30.869\left(\mathrm{C}-2^{\prime}\right)$.

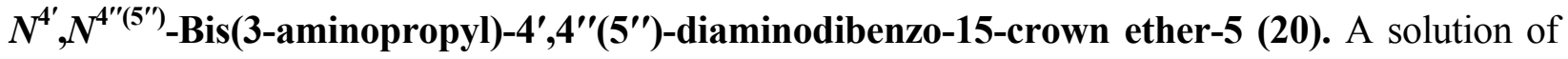
tritylated tetra-amine $19(1.1 \mathrm{~g}, 1.16 \mathrm{mmol})$ in $\mathrm{CH}_{2} \mathrm{Cl}_{2}$ /TFA $(3: 1,10 \mathrm{~mL})$ was kept at ambient temperature for $1 \mathrm{~h}$. Evaporation to dryness, trituration with $\mathrm{Et}_{2} \mathrm{O}$ and refrigeration for $1 \mathrm{~d}$, followed by decantation of the supernatant liquor and repetition of this procedure gave pure tetraamine $20(0.97 \mathrm{~g}, 91 \%)$ as the tetra(trifluoroacetate) salt in the form of a beige foam, $R_{f}(G) 0.02$. HR-MS (m/z): Found $461.2044\left(\mathrm{M}^{+}+1\right), \mathrm{C}_{24} \mathrm{H}_{37} \mathrm{~N}_{4} \mathrm{O}_{5}$ requires $\mathrm{M}^{+}+1=461.2039$.

$N^{7}, N^{13}$-Bis(3-tritylaminopropanoyl)-1,4,10-trioxa-7,13-diazacyclopentadecane (21). To a magnetically stirred solution of aza-oxy crown ether $1(1 \mathrm{~g}, 4.58 \mathrm{mmol})$ in anhydrous DMF $(5 \mathrm{~mL})$ and $\mathrm{CHCl}_{3}(5 \mathrm{~mL})$ were added dry $\mathrm{Et}_{3} \mathrm{~N}(1.4 \mathrm{~mL}, 10 \mathrm{mmol})$, SAE 5 (4.28 g, 10.mmol) and a catalytic amount of $\mathrm{HOBt}(54 \mathrm{mg}, 0.4 \mathrm{mmol})$, and the resulting reaction mixture was stirred at ambient temperature overnight. Dilution with $\mathrm{CHCl}_{3}$, washing with $\mathrm{H}_{2} \mathrm{O}$ (twice), drying and evaporation left a residue from which upon $\mathrm{FCC}$ purification using $\mathrm{CHCl}_{3}$ as eluant and followed by solvent system $\mathrm{G}$ pure bisamide $21(2.28 \mathrm{~g}, 59 \%)$ was obtained as an oil, $\mathrm{R}_{\mathrm{f}}(\mathrm{G})$ 0.85. ESI-MS (m/z): $846.27(M H), 243.11(T r t) . \mathrm{C}_{54} \mathrm{H}_{60} \mathrm{~N}_{4} \mathrm{O}_{5}$ requires $\mathrm{M}^{+}=845.09$. From the same column, monoacylated $1(0.34 \mathrm{~g}, 14 \%)$ was also eluted; ESI-MS $(\mathrm{m} / \mathrm{z}): 532.44(\mathrm{MH})$, 243.11 (Trt). $\mathrm{C}_{32} \mathrm{H}_{41} \mathrm{~N}_{3} \mathrm{O}_{4}$ requires $\mathrm{M}^{+}=531.62$.

$N^{7}, N^{13}$-Bis(3-tritylaminopropanoyl)-1,4,10-trioxa-7,13-diazacyclopentadecane (22). A solution of bisamide $21(2.28 \mathrm{~g}, 2.7 \mathrm{mmol})$ in anhydrous THF $(10 \mathrm{~mL})$ was added dropwise within $1 \mathrm{~h}$ to a magnetically stirred suspension of $\mathrm{LiAlH}_{4}(0.46 \mathrm{~g}, 14 \mathrm{mmol})$ in refluxing THF $(5 \mathrm{~mL})$. The reaction mixture was stirred at this temperature for $1 \mathrm{~d}$ and was then worked-up under an identical manner to that for product 19. Upon FCC purification using solvent system $J$ for elution pure product $22(1.37 \mathrm{~g}, 62 \%)$ was obtained as an oil, $\mathrm{R}_{\mathrm{f}}(\mathrm{J}) 0.57$. ESI-MS $(\mathrm{m} / \mathrm{z})$ : $840.18(M N a), 817.96(M H), 243(\mathrm{Trt})$. HR-MS $(\mathrm{m} / \mathrm{z})$ : Found $817.5049\left(\mathrm{M}^{+}+1\right), \mathrm{C}_{54} \mathrm{H}_{64} \mathrm{~N}_{4} \mathrm{O}_{3}$ requires $\mathrm{M}^{+}+1=817.5057 .{ }^{1} \mathrm{H}$ NMR: $\delta 3.557$ and $3.497(12 \mathrm{H}$, two $\mathrm{m}, \mathrm{H}-2-5, \mathrm{H}-8$ and $\mathrm{H}-9)$, 2.714 (8H, m, H-1, H-6, H-7 and H-10), 2.526 (4H, t, $\left.J=6.8 \mathrm{~Hz}, \mathrm{H}-3^{\prime}\right), 2.131$ (4H, t, $J=6.4 \mathrm{~Hz}$, $\mathrm{H}-1^{\prime}$ ), 1.951 (2H, br. s, NH), 1.649 (4H, quintet, $\left.J=6.8 \mathrm{~Hz}, \mathrm{H}-2^{\prime}\right) .{ }^{13} \mathrm{C}$ NMR: $\delta 71.362(\mathrm{Ph} 3 \mathrm{C}$ ), 71.065 (C-2, C-5, C-8 and C-9), 70.037 (C-3 and C-4), 55.363 (C-1'), 54.681 (C-3'), 42.624 (C1, C-6, C-7 and C-10), 28.733 (C-2').

$N^{4}, N^{13}$-Bis(3'-aminopropyl)-11,7,10-trioxa-4,13-diazacyclopentadecane (23). A solution of crown ether derivative $22(1.47 \mathrm{~g}, 1.8 \mathrm{mmol})$ in $\mathrm{CH}_{2} \mathrm{Cl}_{2} / \mathrm{TFA}(3: 1 ; 8 \mathrm{~mL})$ was kept at ambient temperature for $1 \mathrm{~h}$ and was then concentrated to dryness. The residue was triturated with $\mathrm{Et}_{2} \mathrm{O}$ and refrigerated whereby the product separated as an oil. The supernatant liquor was decanted and this procedure was repeated once more. Thus, the tetra(trifluoroacetate) salt of $\mathbf{2 3}$ (1.38 g, $90 \%)$ was obtained in the form of a yellowish powder, $\mathrm{R}_{\mathrm{f}}(\mathrm{J})$ 0.22. ESI-MS $(\mathrm{m} / \mathrm{z}): 356.11(\mathrm{MNa})$, $334.29(M H)$. HR-MS (m/z): Found 333.2861 $\left(\mathrm{M}^{+}+1\right), \mathrm{C}_{16} \mathrm{H}_{37} \mathrm{~N}_{4} \mathrm{O}_{3}$ requires $\mathrm{M}^{+}+1=333.2866$. 


\section{$N^{7}, N^{16}$-Bis(8-tritylamino-6-oxo-5-azaoctanoyl)-1,4,10,13-tetraoxa-7,16-diazacyclooctadecane}

(24). To a magnetically stirred solution of aza-oxy crown ether $2(0.52 \mathrm{~g}, 2 \mathrm{mmol})$ in anhydrous DMF $(3 \mathrm{~mL})$ and $\mathrm{CHCl}_{3}(1 \mathrm{~mL})$ were added dry $\mathrm{Et}_{3} \mathrm{~N}(0.56 \mathrm{~mL}, 4 \mathrm{mmol})$ and SAE $6(2.05 \mathrm{~g}$, 4.mmol). The resulting reaction mixture was stirred at ambient temperature for $2 \mathrm{~d}$. Dilution with $\mathrm{CHCl}_{3}$, washing with a $5 \%$ aqueous $\mathrm{NaHCO}_{3}$ solution (twice) and with $\mathrm{H}_{2} \mathrm{O}$ (once), drying and evaporation left a residue from which upon FCC purification using the solvent system $\mathrm{F}$ as eluant pure bisamide 24 (1.95 g, 92\%) was obtained as a viscous oil, $\mathrm{R}_{\mathrm{f}}(\mathrm{F})$ 0.23. ESI-MS (m/z): 1,060.31 $(M H), 817.47$ (MH-Trt), 243.09 (Trt). $\mathrm{C}_{64} \mathrm{H}_{78} \mathrm{~N}_{6} \mathrm{O}_{8}$ requires $\mathrm{M}^{+}=1,059.36$.

$N^{7}, N^{16}$-Bis(8-tritylamino-5-azaoctyl)-1,4,10,13-tetraoxa-7,16-diazacyclooctadecane (25). A solution of tetra-amide $24(1.91 \mathrm{~g}, 1.8 \mathrm{mmol})$ in anhydrous THF $(15 \mathrm{~mL})$ was added dropwise within $20 \mathrm{~min}$ to a magnetically stirred suspension of $\mathrm{LiAlH}_{4}(0.72 \mathrm{~g}, 22 \mathrm{mmol})$ in refluxing THF $(5 \mathrm{~mL})$. The reaction mixture was stirred at this temperature for $1 \mathrm{~d}$, and then excess $\mathrm{LiAlH}_{4}$ was carefully destroyed at $-10{ }^{\circ} \mathrm{C}$ by the dropwise addition of a saturated aqueous $\mathrm{Na}_{2} \mathrm{SO}_{4}$ solution. Filtration and washing with more distilled THF followed by evaporation of the filtrates gave a residue which was taken-up in EtOAc. The organic layer was washed twice with brine, dried and evaporated to leave crude hexa-amine derivative 25. Upon FCC purification using solvent system $J$, then system $\mathrm{L}$ and finally system $\mathrm{N}$ for elution pure product $\mathbf{2 5}(1.15 \mathrm{~g}$, $64 \%$ ) was obtained as a viscous oil, $\mathrm{R}_{\mathrm{f}}(\mathrm{N})$ 0.47. ESI-MS $(\mathrm{m} / \mathrm{z}): 1026(\mathrm{MNa}), 1004(\mathrm{MH}), 656$ $\left[M \mathrm{Na}-\mathrm{TrtNH}\left(\mathrm{CH}_{2}\right)_{3} \mathrm{NH}\left(\mathrm{CH}_{2}\right)_{2} \mathrm{CH}=\mathrm{CH}_{2}\right], 633656\left[\mathrm{MH}-\mathrm{TrtNH}\left(\mathrm{CH}_{2}\right)_{3} \mathrm{NH}\left(\mathrm{CH}_{2}\right)_{2} \mathrm{CH}=\mathrm{CH}_{2}\right], 243$ (Trt). $\mathrm{C}_{64} \mathrm{H}_{86} \mathrm{~N}_{6} \mathrm{O}_{4}$ requires $\mathrm{M}^{+}=1003.42 .{ }^{1} \mathrm{H}-\mathrm{NMR}$ : $\delta 3.594(16 \mathrm{H}, \mathrm{m}, \mathrm{H}-2-5$ and H-8-11), 2.753 $\left(8 \mathrm{H}, \mathrm{t}, J=5.6 \mathrm{~Hz}, \mathrm{H}-1, \mathrm{H}-6, \mathrm{H}-7\right.$ and H-12), 2.674 (4H, t, $\left.J=6.8 \mathrm{~Hz}, \mathrm{H}-1^{\prime}\right), 2.589$ (4H, m, H-4'), $2.489\left(4 \mathrm{H}, \mathrm{m}, \mathrm{H}-6^{\prime}\right), 2.183\left(4 \mathrm{H}, \mathrm{t}, J=6.4 \mathrm{~Hz}, \mathrm{H}-8^{\prime}\right), 1.671$ (4H, quintet, $\left.J=6.4 \mathrm{~Hz}, \mathrm{H}-7^{\prime}\right), 1.464$ (8H, m, H-2' and $\left.\mathrm{H}-3^{\prime}\right) .{ }^{13} \mathrm{C}$ NMR: $\delta 71.364\left(\mathrm{Ph}_{3} \mathrm{C}\right), 71.148$ (C-3, C-4, C-9 and C-10), $70.420(\mathrm{C}-$ 2, C-5, C-8 and C-11), 56.250 (C-1'), 54.410 (C-1, C-6, C-7 and C-12), 50.335 (C-4'), 48.824 (C-6'), $42.512\left(\mathrm{C}-8^{\prime}\right), 31.323\left(\mathrm{C}-2^{\prime}\right), 28.446\left(\mathrm{C}-3^{\prime}\right), 25.698$ (C-7') .

$N^{7}, N^{16}$-Bis(8-amino-5-azaoctyl)-1,4,10,13-tetraoxa-7,16-diazacyclooctadecane (26). A solution of bistritylated hexa-amine $25(1.1 \mathrm{~g}, 1.1 \mathrm{mmol})$ in $\mathrm{CH}_{2} \mathrm{Cl}_{2} / \mathrm{TFA}(3: 1,10 \mathrm{~m})$ was kept at ambient temperature for $1 \mathrm{~h}$ and was then concentrated to dryness. The residue was triturated with $\mathrm{Et}_{2} \mathrm{O}$ and refrigerated whereby the product separated as an oil. The supernatant liquor was decanted and this procedure was repeated once more to furnish $26(1.19 \mathrm{~g}, .90 \%)$ as the hexa(trifluoroacetate) salt in the form of a brownish powder, $\mathrm{R}_{\mathrm{f}}(\mathrm{N}) 0.07$. HR-MS $(\mathrm{m} / \mathrm{z})$ : Found $519.4589\left(\mathrm{M}^{+}+1\right), \mathrm{C}_{26} \mathrm{H}_{59} \mathrm{~N}_{6} \mathrm{O}_{4}$ requires $\mathrm{M}^{+}+1=519.4598$.

Reaction of epichlohydrin (27) with dibenzylamine, Formation of a mixture of 1dibenzylamino-3-chloro-2-propanol (28) and dibenzylaminomethyloxirane (29). A solution consisting of $27(30 \mathrm{~mL}, 0.38 \mathrm{~mol}), \mathrm{Bn} 2 \mathrm{NH}(20 \mathrm{~mL}, 0.1 \mathrm{~mol})$ and anhydrous iPr2NEt $(20 \mathrm{~mL}$, 0.11 mol) was kept at $110{ }^{\circ} \mathrm{C}$ (bath temperature) for $2 \mathrm{~h}$. It was then diluted with Et2O and washed sequentially with a $5 \%$ aqueous $\mathrm{NaHCO} 3$ solution, with $\mathrm{H} 2 \mathrm{O}$ (twice), and with brine (once), dried and evaporated to dryness to leave an oily residue. From this oil, upon purification by FCC using PhMe as the eluant mixture consisted of chlorohydrin 28 and epoxide 29 (18.34 g; ratio 3:2 by $1 \mathrm{H}$ NMR) was obtained. This mixture was used as such for the next experiment. 
However, in a small scale experiment ( $2 \mathrm{~mL}$ from each of Bn2NH and iPr2NEt and $3 \mathrm{~mL}$ of 27), the resulting mixture was separated by FCC using solvent system A as eluant to give pure alcohol 28 and epoxide 29, both as oils.

Chlorohydrin 28: $\mathrm{R}_{\mathrm{f}}(\mathrm{PhMe} / \mathrm{EtOAc}=98: 2)$ 0.24. ${ }^{1} \mathrm{H}$ NMR: $\delta$ 7.35-7.23 $(10 \mathrm{H}, \mathrm{m}, \mathrm{Ph}-\mathrm{H}), 3.751$ $(1 \mathrm{H}, \mathrm{dq}, J=8.6$ and $5.2 \mathrm{~Hz}, \mathrm{CH}-\mathrm{OH}), 3.753$ and $3.503\left(4 \mathrm{H}\right.$, two d-ABq, $J=13.4 \mathrm{~Hz}, \mathrm{NCH}_{2} \mathrm{Ph}$ ), $3.450\left(2 \mathrm{H}, \mathrm{dd}, J=5.0\right.$ and $\left.3.1 \mathrm{~Hz}, \mathrm{CH}_{2} \mathrm{Cl}\right), 3.225(1 \mathrm{H}$, br. s, $\mathrm{OH}), 2.631(1 \mathrm{H}, \mathrm{dd}, J=11.9$ and 4.8 $\mathrm{Hz}, \mathrm{CHCH}_{2} \mathrm{~N}$ ) and $2.587\left(1 \mathrm{H}, \mathrm{dd}, J=11.9\right.$ and $\left.8.5 \mathrm{~Hz}, \mathrm{CHCH}_{2} \mathrm{~N}\right) .{ }^{13} \mathrm{C}$ NMR: $\delta 138.754$ (ipso C), 129.470 (o-C), $128.938(m-\mathrm{C}), 127.835(p-\mathrm{C}), 68.211(\mathrm{CH}-\mathrm{OH}), 59.298\left(\mathrm{NCH}_{2} \mathrm{Ph}\right), 57.178$ $\left(\mathrm{CH}_{2} \mathrm{Cl}\right), 45.451\left(\mathrm{NCH}_{2} \mathrm{CH}\right)$. Anal. Calcd for $\mathrm{C}_{17} \mathrm{H}_{20} \mathrm{ClNO}$ (289.81): C, 70.46; H, 6.96; N, 4.83 . Found: C, 70.26; H, 7.10; N, 4.97.

Epoxide 29: $\mathrm{R}_{\mathrm{f}}(\mathrm{PhMe} / \mathrm{EtOAc}=98: 2)$ 0.32. ${ }^{1} \mathrm{H}$ NMR: $\delta$ 7.37-7.20 $(10 \mathrm{H}, \mathrm{m}, \mathrm{Ph}-\mathrm{H}), 3.796$ and $3.557\left(4 \mathrm{H}\right.$, two d-ABq, $\left.J=13.7 \mathrm{~Hz}, \mathrm{NCH}_{2} \mathrm{Ph}\right), 3.067(1 \mathrm{H}, \mathrm{dq}, J=6.4$ and $3.7 \mathrm{~Hz}, \mathrm{CH}-\mathrm{O}), 2.760$ $\left(1 \mathrm{H}, \mathrm{dd}, J=13.8\right.$ and $\left.3.6 \mathrm{~Hz}, \mathrm{CH}_{2} \mathrm{O}\right), 2.652\left(1 \mathrm{H}, \mathrm{t}, J=4.5 \mathrm{~Hz}, \mathrm{NCH}_{2} \mathrm{CH}\right), 2.405(1 \mathrm{H}, \mathrm{dd}, J=$ 13.8 and $\left.6.3 \mathrm{~Hz}, \mathrm{CH}_{2} \mathrm{O}\right), 2.391\left(1 \mathrm{H}, \mathrm{dd}, J=5.0\right.$ and $\left.2.8 \mathrm{~Hz}, \mathrm{NCH}_{2} \mathrm{CH}\right) .{ }^{13} \mathrm{C}$ NMR: $\delta 139.802$ (ipso C), $129.265(o-C), 128.701(m-\mathrm{C}), 127.427(p-\mathrm{C}), 59.410\left(\mathrm{NCH}_{2} \mathrm{Ph}\right), 56.315(\mathrm{CH}-\mathrm{O})$, $51.520\left(\mathrm{CH}_{2} \mathrm{O}\right), 45.443\left(\mathrm{NCH}_{2} \mathrm{CH}\right)$.Anal. Calcd for $\mathrm{C}_{17} \mathrm{H}_{19} \mathrm{NO}$ (253.34): C, 80.60; H, 7.56; N, 5.53. Found: C, 80.38; H, 7.70; N, 5.81 .

Conversion of the mixture of chlorohydrin 28 and epoxide 29 to epoxide 29 and reaction of the latter with DEG. Preparation of 9-dibenzylamino-3,6-dioxanonane-1,8-diol (30). A solution consisted of chlorohydrin $28(3.5 \mathrm{~g}, 12 \mathrm{mmol})$ and epoxide $29(2 \mathrm{~g}, 8 \mathrm{mmol})$ in anhydrous THF $(15 \mathrm{~mL})$ was added dropwise within $30 \mathrm{~min}$ to two-necked round bottom flask equipped with a side-armed dropping funnel containing $\mathrm{NaH}(0.29 \mathrm{~g}, 12 \mathrm{mmol})$ and a catalytic amount of imidazole. The resulting reaction mixture was stirred at ambient temperature for a further $1 \mathrm{~h}$ and then filtered. The precipitate was washed with THF $(10 \mathrm{~mL})$, and the filtrate containing pure (by TLC) epoxide $\mathbf{2 9}$ was used as such to the following experiment.

DEG (19 mL, $0.2 \mathrm{~mol})$ was added dropwise within $15 \mathrm{~min}$ to a magnetically stirred suspension of $\mathrm{NaH}(0.1 \mathrm{~g}, 4 \mathrm{mmol})$ in anhydrous THF $(10 \mathrm{~mL})$ placed in a two-necked round bottom flask equipped with a side-armed dropping funnel and a reflux condenser. It was then heated to reflux, and the above described solution of $\mathbf{2 9}$ was added dropwise from the dropping funnel within $2.5 \mathrm{~h}$. Reflux was kept on for additional $2 \mathrm{~d}$. THF was then evaporated, and the residue was dissolved in EtOAc and washed three times with brine. Drying and evaporation left an oily residue from which after FCC using the solvent system F as eluant pure TEG derivative $30(5.4 \mathrm{~g}, 75 \%)$ was obtained as an oil, $\mathrm{R}_{\mathrm{f}}(\mathrm{F})$ 0.38. ESI-MS $(\mathrm{m} / \mathrm{z}): 741.65(2 \mathrm{M}+\mathrm{Na}), 719.69$ $(2 \mathrm{M}+\mathrm{H}), 382.34(M \mathrm{Na}), 360.42(M \mathrm{H}) .{ }^{1} \mathrm{H}$ NMR: $\delta$ 7.33-7.23 (10H, m, Ph-H), $3.912(1 \mathrm{H}, \mathrm{m}, \mathrm{H}-$ 6), 3.741 (2H, d, $J=13.4 \mathrm{~Hz}, \mathrm{H}-8), 3.680(2 \mathrm{H}, \mathrm{t}, J=4.6 \mathrm{~Hz}, \mathrm{H}-1), 3.609-3.551$ (6H, m, H-2-4), $3.520\left(2 \mathrm{H}, \mathrm{d}, J=13.5 \mathrm{~Hz}, \mathrm{H}-8^{\prime}\right), 3.483(1 \mathrm{H}, \mathrm{dd}, J=10.2$ and $3.7 \mathrm{~Hz}, \mathrm{H}-5), 3.533(1 \mathrm{H}, \mathrm{dd}, J=$ 10.2 and $\left.6.4 \mathrm{~Hz}, \mathrm{H}-5^{\prime}\right), 2.557(1 \mathrm{H}, \mathrm{dd}, J=12.8$ and $8.4 \mathrm{~Hz}, \mathrm{H}-7), 2.504(1 \mathrm{H}, \mathrm{dd}, J=12.9$ and 5.1 Hz, H-7'). ${ }^{13} \mathrm{C}$ NMR: $\delta 139.095$ (ipso C), 129.429 (o-C), 128.793 (m-C), 127.611 (p-C), 74.847 (C-6), 72.915 (C-1), 71.182 (C-2), 70.711 (C-5), 67.569 (C-4), 62.111 (C-3), 59.028 (C-8), 
56.413 (C-7). Anal. Calcd for $\mathrm{C}_{21} \mathrm{H}_{29} \mathrm{NO}_{4}$ (359.46): C, 70.17; H, 8.13; N, 3.90. Found: C, 70.47; $\mathrm{H}, 7.94 ; \mathrm{N}, 3,70$.

2-Dibenzylaminomethyl-18-crown ether-6 (31). To a solution of diol $\mathbf{3 0}$ (4.8 g, $13.4 \mathrm{mmol})$ in anhydrous DMSO $(50 \mathrm{~mL})$ was first added $\mathrm{NaH}(2.68 \mathrm{~g}$ of a $60 \%$ dispersion in oil, $67 \mathrm{mmol})$ and then TGT $(6.15 \mathrm{~g}, 13.4 \mathrm{mmol})$. The resulting reaction mixture was stirred at ambient temperature for $2 \mathrm{~d}$ and then diluted with $\mathrm{H}_{2} \mathrm{O}(150 \mathrm{~mL})$ and brine $(50 \mathrm{~mL})$. The resulting mixture was extracted three times with $\mathrm{Et}_{2} \mathrm{O}$, the organic layers were combined, washed three times with brine and finally dried (anhydrous $\mathrm{MgSO}_{4}$ ) and evaporated to dryness to leave an oily residue. This residue was subjected to FCC using solvent system $\mathrm{G}$ as eluant to give pure product $31(3.62 \mathrm{~g}, 57 \%)$ as an oil, $\mathrm{R}_{\mathrm{f}}(\mathrm{G})$ 0.20. ESI-MS $(\mathrm{m} / \mathrm{z}): 513.46(M \mathrm{~K}), 496.49(\mathrm{MNa})$, $474.46(\mathrm{MH}) .{ }^{1} \mathrm{H}$ NMR: $\delta$ 7.34-7.20 (10H, m, Ph-H), 3.81-3.32 (24H, m, CHO, $\mathrm{CH}_{2} \mathrm{O}$ and $\left.\mathrm{NCH}_{2} \mathrm{Ph}\right), 2.563\left(1 \mathrm{H}, \mathrm{dd}, J=12.6\right.$ and $\left.5.7 \mathrm{~Hz}, \mathrm{OCHCH}_{2} \mathrm{~N}\right), 2.506(1 \mathrm{H}, \mathrm{dd}, J=12.6$ and $4.8 \mathrm{~Hz}$, $\mathrm{OCHCH}_{2} \mathrm{~N}$ ). Anal. Calcd for $\mathrm{C}_{27} \mathrm{H}_{39} \mathrm{NO}_{6}$ (473.60): C, 68.47; H, 8.30; N, 2.96. Found: C, 68.70; $\mathrm{H}, 8.05 ; \mathrm{N}, 2.69$.

2-Aminomethyl-18-crown ether-6 (3). To a solution of crown ether $31(2.2 \mathrm{~g}, 4.6 \mathrm{mmol})$ in $\mathrm{MeOH}(30 \mathrm{~mL})$ was added of Pearlman's catalyst $(0.5 \mathrm{~g})$, and the resulting mixture was subjected to catalytic hydrogenation at $3 \mathrm{~atm}$ pressure at ambient temperature for $3 \mathrm{~d}$. Filtration of the catalyst and evaporation of the $\mathrm{MeOH}$ filtrate to dryness left the oily crown ether 3 ( $1.3 \mathrm{~g}$, $96 \%), R_{f}(G) 0.11$. This product 3 was identical in all respects with a commercially available sample and was used without any further purification in the preparation of amide 32a.

2-(5'-Tritylamino-3'-oxo-2'-azapentyl)-1,4,7,10,13,16-hexaoxacyclohexadecane (32a). To a solution of aminomethyl crown $3(1.3 \mathrm{~g}, 4.43 \mathrm{mmol})$ and dry $^{2} t_{3} \mathrm{~N}(0.62 \mathrm{~mL}, 4.43 \mathrm{mmol})$ in anhydrous DMF $(5 \mathrm{~mL})$ was added in three equal portions within 30 min SAE 5 (1.9 g, $4.43 \mathrm{mmol}$ ). The resulting solution was kept at ambient temperature overnight and was then diluted with $\mathrm{CHCl}_{3}$ and washed sequentially with a $5 \%$ aqueous $\mathrm{NaHCO}_{3}$ solution (twice) and with brine (once), dried $\left(\mathrm{MgSO}_{4}\right)$ and evaporated to dryness to leave an oily residue. Following FCC purification with solvent system $\mathrm{J}$ as eluant pure amide 32a $(2.5 \mathrm{~g}, 93 \%)$ was obtained as a foam, $\mathrm{R}_{\mathrm{f}}(\mathrm{J})$ 0.19. FT-IR: $3322(\mathrm{NH}), 1652(\mathrm{NHCO}) \mathrm{cm}^{-1}$. ESI-MS (m/z): 1,214.08 (2M+H), $646.48(\mathrm{MK})$, $629.71(M \mathrm{Na}), 607.76(M \mathrm{H}), 243(\mathrm{Trt}) . \mathrm{C}_{35} \mathrm{H}_{46} \mathrm{~N}_{2} \mathrm{O}_{7}$ requires $\mathrm{M}^{+}=606.76$.

2-(14'-Tritylamino-3', $7^{\prime}, 12^{\prime}$-trioxo-2', $6^{\prime}, 11^{\prime}$-triazatetradecyl)-1,4,7,10,13,16-hexaoxacyclohexadecane(33). A solution of amide 32a $(1.2 \mathrm{~g}, 2 \mathrm{mmol})$ in $\mathrm{CH}_{2} \mathrm{Cl}_{2} / \mathrm{TFA}(1: 1 ; 8 \mathrm{~mL})$ was kept at ambient temperature for 30 min. It was then evaporated to dryness, triturated with $\mathrm{Et}_{2} \mathrm{O}$ and refrigerated overnight. The supernatant liquor was decanted and the residue was trituration with $\mathrm{Et}_{2} \mathrm{O}$ followed by refrigeration; finally decantation was repeated to leave the trifluoroacetate salt of 32b $(0.91 \mathrm{~g}, 95 \%)$ as a thick oil. HR-MS (m/z): Found $365.2231\left(\mathrm{M}^{+}+1\right), \mathrm{C}_{16} \mathrm{H}_{33} \mathrm{~N}_{2} \mathrm{O}_{7}$ requires $\mathrm{M}^{+}+1=365.2228$.

This oil was dissolved in anhydrous DMF $(3 \mathrm{~mL})$ and treated at $0{ }^{\circ} \mathrm{C}$ in turn with $\mathrm{Et}_{3} \mathrm{~N}$ $(0.5 \mathrm{~mL}, 3.8 \mathrm{mmol})$ and SAE $6(0.98 \mathrm{~g}, 1.9 \mathrm{mmol})$ for $1 \mathrm{~h}$ and then at ambient temperature for $1 \mathrm{~d}$. Identical work-up as for 32a and FCC purification using solvent system $\mathrm{G}$ for elution gave pure trisamide $33(1.13 \mathrm{~g}, 79 \%)$ as a foam, $\mathrm{R}_{\mathrm{f}}(\mathrm{G})$ 0.26. FT-IR: $3284(\mathrm{NH}), 1652(\mathrm{NHCO}) \mathrm{cm}^{-1}$. 
ESI-MS (m/z): $801.62(M K), 785.60(M N a), 763.75(M H), 243(T r t)$. HR-MS (m/z): Found $763.4292\left(\mathrm{M}^{+}+1\right), \mathrm{C}_{42} \mathrm{H}_{59} \mathrm{~N}_{4} \mathrm{O}_{9}$ requires $\mathrm{M}^{+}+1=763.4282$.

2-( $N^{2^{\prime}}, N^{6^{\prime}}, N^{11^{\prime}}$-Tris(benzyloxycarbonyl)-14'-tritylamino-2', $6^{\prime}, 1^{\prime}$-triazatetradecyl)-

$\mathbf{1 , 4 , 7 , 1 0 , 1 3 , 1 6 - h e x a o x a c y c l o h e x a d e c a n e ~ ( 3 4 ) . ~ A ~ s o l u t i o n ~ o f ~ t r i s a m i d e ~} 33(0.7 \mathrm{~g}, 0.92 \mathrm{mmol})$ in anhydrous THF $(8 \mathrm{~mL})$ was added dropwise within $30 \mathrm{~min}$ to a magnetically stirred suspension of $\mathrm{LiAlH}_{4}(0.31 \mathrm{~g}, 8.3 \mathrm{mmol})$ in refluxing THF $(3 \mathrm{~mL})$. The reaction mixture was stirred at this temperature for $4 \mathrm{~d}$ and was then worked-up as described for the preparation of 10a to give crude tetra-amine $34(0.45 \mathrm{~g}, 0.63 \mathrm{mmol})$. This was dissolved in dry $\mathrm{CHCl}_{3}(5 \mathrm{~mL})$ and treated at $0{ }^{\circ} \mathrm{C}$ in turn with anhydrous ${ }^{\mathrm{i}} \mathrm{Pr}_{2} \mathrm{NEt}(0.43 \mathrm{~mL}, 2.5 \mathrm{mmol})$ and $\mathrm{ZCl}(0.29 \mathrm{~mL}, 2 \mathrm{mmol})$ for $30 \mathrm{~min}$ and at ambient temperature for overnight. The resulting solution was diluted with $\mathrm{CHCl}_{3}$ and washed sequentially twice with a $5 \%$ aqueous $\mathrm{NaHCO}_{3}$ solution and once with $\mathrm{H}_{2} \mathrm{O}$, dried $\left(\mathrm{MgSO}_{4}\right)$ and evaporated to leave an oily residue. Upon FCC purification using solvent system $\mathrm{F}$ for elution pure product $34(0.60 \mathrm{~g}, 60 \%$ based on trisamide 33$)$ was obtained as an oil, $\mathrm{R}_{\mathrm{f}}(\mathrm{F})$ 0.36. HR-MS $(\mathrm{m} / \mathrm{z})$ : Found 1,123.6032 $\left(\mathrm{M}^{+}+1\right), \mathrm{C}_{66} \mathrm{H}_{83} \mathrm{~N}_{4} \mathrm{O}_{12}$ requires $\mathrm{M}^{+}+1=1,123.6008$.

2-( $\left(N^{2^{\prime}}, N^{6^{\prime}}, N^{11^{\prime}}\right.$-Tris(benzyloxycarbonyl)-14' -[bis(benzyloxycarbonyl)guanidyl]-2' $, 6^{\prime}, 1^{\prime}{ }^{\prime}$ triazatetradecyl-1,4,7,10,13,16-hexaoxacyclohexadecane (36). Intermediate $34(0.16 \mathrm{~g}$, $0.14 \mathrm{mmol}$ ) was detritylated under identical way to that for amide 32a to give the trifluoroacetate salt of $35(0.12, \mathrm{~g} 85 \%)$ as an oil. ESI-MS (m/z): $882.50(M \mathrm{H}), 881.51(M) . \mathrm{C}_{47} \mathrm{H}_{68} \mathrm{~N}_{4} \mathrm{O}_{12}$ requires $\mathrm{M}^{+}=881.08$. This oil was dissolved in anhydrous $\mathrm{CHCl}_{3}(0.5 \mathrm{~mL})$ and treated at $0{ }^{\circ} \mathrm{C}$ in turn with $i \operatorname{Pr}_{2} \mathrm{NEt}(0.044 \mathrm{~mL}, 0.25 \mathrm{mmol})$ and the reagent BZMTU $(0.043 \mathrm{~g}, 0.12 \mathrm{mmol})$ for $30 \mathrm{~min}$ and at ambient temperature overnight. Identical work-up as for $\mathbf{3 4}$ and final FCC purification with solvent system $F$ gave pure, fully protected, intermediate $36(0.13 \mathrm{~g}, 82 \%)$ as a foam, $\mathrm{R}_{\mathrm{f}}(\mathrm{F})$ 0.11. ESI-MS (m/z): 1,230.64 (MK), 1,214.63 (MNa), 1,191.67 (M), 608.02 $[(\mathrm{M}+\mathrm{H}+\mathrm{Na}) / 2] . \mathrm{C}_{64} \mathrm{H}_{82} \mathrm{~N}_{6} \mathrm{O}_{16}$ requires $\mathrm{M}^{+}=1,191.39$.

2-(14'-guanidyl-2', $6^{\prime}, 11^{\prime}$-triazatetradecyl)-1,4,7,10,13,16-hexaoxacyclohexadecane (37). To a solution of fully protected polyamine $36(0.12 \mathrm{~g}, 0.1 \mathrm{mmol})$ in glacial $\mathrm{AcOH}(4 \mathrm{~mL}), \mathrm{MeOH}$ $(1 \mathrm{~mL})$ and $\mathrm{H}_{2} \mathrm{O}(0.1 \mathrm{~mL})$ was added $\mathrm{Pd}$ on $\mathrm{C}(10 \% ; 0.03 \mathrm{~g})$, and the resulting reaction mixture was hydrogenated at ambient temperature for $6 \mathrm{~h}$. Filtration and evaporation gave pure product 37, $\mathrm{R}_{\mathrm{f}}(\mathrm{L})$ 0.27. This product was dissolved in a solution of $\mathrm{HCl}$ in anhydrous $\mathrm{MeOH}(1.8 \mathrm{M}$, $1 \mathrm{~mL})$. Trituration with $\mathrm{Et}_{2} \mathrm{O}$ and refrigeration gave the tetrahydrochloride of polyamine 37 $(0.054 \mathrm{~g}, 70 \%)$ as a powder. HR-MS (m/z): Found $521.4038\left(\mathrm{M}^{+}+1\right), \mathrm{C}_{24} \mathrm{H}_{53} \mathrm{~N}_{6} \mathrm{O}_{6}$ requires $\mathrm{M}^{+}+1$ $=521.4027$.

1,8-Diido-3,6-dioxaoctane (TGI) and 1,11-Diido-3,6,9-trioxaundecane (TEGI). To a magnetically stirred solution of either TGT $(4.59 \mathrm{~g}, 10 \mathrm{mmol})$ or TEGT $(5.03 \mathrm{~g}, 10 \mathrm{mmol})$ in acetone $(60 \mathrm{~mL})$. $\mathrm{NaI}(6 \mathrm{~g}, 40 \mathrm{mmol})$ was added, and the resulting reaction mixture was stirred at ambient temperature for $1 \mathrm{~d}$. Filtration and evaporation of the solvent left a residue which was triturated with $\mathrm{Et}_{2} \mathrm{O}$ and refrigerated for overnight. Filtration and evaporation of the solvent left the pure diiodides in quantitative yield as pale red liquids which were used as such without any further purification for the preparation of the aza-oxa crown ethers. 
Preparation of 3-oxapentane-1,5-diamine (39) as bisphthalylhydrazide.salt. A solution of DGT (11.03 g, $26.6 \mathrm{mmol})$ and potassium phthalimide (9.85 g, $53.2 \mathrm{mmol})$ in DMF (25 mL) was heated at $100-20{ }^{\circ} \mathrm{C}$ (bath temperature) overnight. It was then diluted with $\mathrm{CHCl}_{3}$ and washed in turn with a aqueous $\mathrm{NaOH}(2 \mathrm{~N})$ and with brine (twice) and $\mathrm{H}_{2} \mathrm{O}$ (twice). Drying and evaporation left a residue which upon trituration with $\mathrm{Et}_{2} \mathrm{O}$ and overnight refrigeration gave pure bisphthalimide 38 (4.85 g, 50\%), $\mathrm{R}_{\mathrm{f}}(\mathrm{C}) 0.36$.

Bisphthalimide 38 (4.8 g, $13.2 \mathrm{mmol})$ and hydrazine monohydrate (1.28 mL, $26.4 \mathrm{mmol})$ were heated under reflux in $\mathrm{MeOH}(15 \mathrm{~mL})$ for $30 \mathrm{~min}$. The reaction mixture was then refrigerated overnight and the precipitated product the bisphthalyl-hydrazide salt of 39 (3.9 g, $69 \%$ ) was obtained by filtration and washing with ice-cold $\mathrm{MeOH}$. This salt was used as such for the preparation of bisamide $\mathbf{4 0 .}$

$\boldsymbol{N}^{1}, \boldsymbol{N}^{13}$-Ditritylamino-3,11-dioxo-7-oxa-4,10-diazatridecane (40). To a magnetically stirred, ice-cold solution of salt $39(3.43 \mathrm{~g}, 8 \mathrm{mmol})$ in dry DMF $(30 \mathrm{~mL})$ was added anhydrous $\mathrm{Et}_{3} \mathrm{~N}$ (4.5 mL, $32 \mathrm{mmol})$, followed by SAE 5 (6.86 g, $16 \mathrm{mmol})$. The reaction mixture was stirred at this temperature for $30 \mathrm{~min}$ and then at ambient temperature overnight.. It was then diluted with $\mathrm{CHCl}_{3}$, washed in turn with aqueous $\mathrm{NaHCO}_{3}$ solution $\left(5 \%\right.$, twice) and with $\mathrm{H}_{2} \mathrm{O}$ (three times), dried, evaporated, and the residue was triturated with EtOAc. Overnight refrigeration gave pure bisamide 40 (4.5 g, 77\%), mp 164-65 ${ }^{\circ} \mathrm{C}$; $\mathrm{R}_{\mathrm{f}}(\mathrm{G})$ 0.71. FT-IR: 3328 and $3254(\mathrm{NH}), 1646$ (NHCO) $\mathrm{cm}^{-1}$. ESI-MS (m/z): 731.87 (MH), 489.64 (M-Trt), 243 (Trt). ${ }^{1} \mathrm{H}$ NMR: $\delta 6.678(2 \mathrm{H}, \mathrm{t}, J=$ $5.2 \mathrm{~Hz}, \mathrm{H}-4$ and H-10), 3.544 (4H, t, $J=5.2 \mathrm{~Hz}, \mathrm{H}-6$ and H-8), 3.395 (4H, q, $J=5.2 \mathrm{~Hz}, \mathrm{H}-5$ and $\mathrm{H}-9), 2.364(4 \mathrm{H}, \mathrm{t}, J=6.0 \mathrm{~Hz}, \mathrm{H}-1$ and $\mathrm{H}-13), 2.131(4 \mathrm{H}, \mathrm{t}, J=6.0 \mathrm{~Hz}, \mathrm{H}-2$ and $\mathrm{H}-12) .{ }^{13} \mathrm{C}$ NMR: $\delta 172.796$ (C-3 and C-11), $71.452\left(\mathrm{Ph}_{3} \mathrm{C}\right), 70.540$ (C-6 and C-8), 40.226 (C-5 and C-9), 39.512 (C-1 and C-13), 37.259 (C-2 and C-12) .Anal. Calcd for $\mathrm{C}_{48} \mathrm{H}_{50} \mathrm{~N}_{4} \mathrm{O}_{3}$ (730.96): C, 78.87; H, 6.90; N, 7.76. Found: C, 78.59; H, 7.05; N, 7.99.

$\boldsymbol{N}^{\mathbf{1}}, \boldsymbol{N}^{\mathbf{1 3}}$-Ditrityl-1,13-diamino-7-oxa-4,10-diazatridecane (41). Bisamide 40 (4.53 g, $6.2 \mathrm{mmol}$ ) was treated with $\mathrm{LiAlH}_{4}(1.4 \mathrm{~g}, 37 \mathrm{mmol})$ in anhydrous THF $(50 \mathrm{~mL})$ for $2 \mathrm{~d}$, and the resulting reaction mixture was worked-up in an identical way to that described for 9a to give pure product 41 (3.7 g, 85\%), $111-12{ }^{\circ} \mathrm{C}, \mathrm{R}_{\mathrm{f}}(\mathrm{J})$ 0.42. ESI-MS (m/z): $703.80(M \mathrm{H}) .{ }^{1} \mathrm{H}$ NMR: $\delta 3.530(4 \mathrm{H}, \mathrm{t}, J$ $=5.2 \mathrm{~Hz}, \mathrm{H}-6$ and H-8), $2.733(4 \mathrm{H}, \mathrm{t}, J=5.2 \mathrm{~Hz}, \mathrm{H}-5$ and H-9), 2.643 (4H, t, $J=6.8 \mathrm{~Hz}, \mathrm{H}-1$ and H-13), 2.148 (4H, unresolved t, H-3 and H-11), $1.696(2 \mathrm{H}$, br. s, H-4 and H-10), 1.621 (4H, quintet, $J=6.8 \mathrm{~Hz}, \mathrm{H}-2$ and $\mathrm{H}-12) .{ }^{13} \mathrm{C}$ NMR: $\delta 71.310\left(\mathrm{Ph}_{3} \mathrm{C}\right), 70.997(\mathrm{C}-6$ and $\mathrm{C}-8), 49.869$ (C-5 and C-9), 48.974 (C-1 and C-13), 42.552 (C-3 and C-11), 31.480 (C-2 and C-12). Anal. Calcd for $\mathrm{C}_{48} \mathrm{H}_{54} \mathrm{~N}_{4} \mathrm{O}$ (702.99): C, 82.01; H, 7.74; N, 7.97. Found: C, 82.21; H, 7.35; N, 7.77.

$N^{4}, N^{13}$-Di(3'-tritylaminopropyl)-11,7,10-trioxa-4,13-diazacyclopentadecane (22) from tetraamine derivative 41. To a solution of tetra-amine derivative 41 (1.2 g, $1.7 \mathrm{mmol})$ and diiodide TGI (0.63 g, $1.7 \mathrm{mmol})$ in anhydrous $\mathrm{MeCN}(30 \mathrm{~mL})$ was added $\mathrm{Na}_{2} \mathrm{CO}_{3}(1.04 \mathrm{~g}, 10 \mathrm{mmol})$, and the resulting mixture was refluxed in an atmosphere of Ar for $2 \mathrm{~d}$. It was then refrigerated, filtered, and the residue on the filter was washed with ice-cold $\mathrm{MeCN}$. The filtrate was evaporated, and the residue was dissolved in EtOAc and washed with $\mathrm{H}_{2} \mathrm{O}$ (twice). Drying 
$\left(\mathrm{MgSO}_{4}\right)$, filtration and evaporation left a residue from which after FCC purification and using solvent system $J$ as eluant the pure product $22(1.01 \mathrm{~g}, 73 \%)$ was obtained as a foam.

$N^{4}, N^{16}$-Di(3'-tritylaminopropyl)-1,7,10,13-tetraoxa-4,16-diazacyclooctadecane (42). Under identical reaction conditions and work-up, compound 41 (0.98 g, $1.4 \mathrm{mmol})$, diiodide TEGI $(0.58 \mathrm{~g}, 1.4 \mathrm{mmol})$ and $\mathrm{K}_{2} \mathrm{CO}_{3}(1.11 \mathrm{~g}, 8 \mathrm{mmol})$ in anhydrous $\mathrm{MeCN}(30 \mathrm{~mL})$ gave after FCC purification with solvent system $\mathrm{H}$ as eluant the pure product $42(0.80 \mathrm{~g}, 66 \%)$ as a foam, $\mathrm{R}_{\mathrm{f}}(\mathrm{H})$ 0.33. ESI-MS (m/z): $862.04(M H)$. HR-MS (m/z): Found $861.5332\left(\mathrm{M}^{+}+1\right), \mathrm{C}_{56} \mathrm{H}_{69} \mathrm{~N}_{4} \mathrm{O}_{4}$ requires $\mathrm{M}^{+}+1=861.5319 .{ }^{1} \mathrm{H}$ NMR: $\delta 3.586$ and $3.509\left(16 \mathrm{H}\right.$, two $\left.\mathrm{m}, \mathrm{CH}_{2} \mathrm{O}\right), 2.776(8 \mathrm{H}, \mathrm{m}, \mathrm{C}-1, \mathrm{C}-6$, C-7 and C-10), 2.596 (4H, m, C-1'), 2.118 (4H, t, $\left.J=6.8 \mathrm{~Hz}, \mathrm{H}-3^{\prime}\right), 1.654$ (4H, quintet, $J=$ $\left.6.4 \mathrm{~Hz}, \mathrm{H}-2^{\prime}\right)$.

$N^{4}, N^{16}$-Di(3'-aminopropyl)-1,7,10,13-tetraoxa-4,16-diazacyclooctadecane (43). Under identical reaction conditions and work-up procedure as for $\mathbf{2 3}$, aza-crown derivative $\mathbf{4 2}(0.8 \mathrm{~g}$, $0.94 \mathrm{mmol})$ in $\mathrm{CH}_{2} \mathrm{Cl}_{2} / \mathrm{TFA}(3: 1 ; 4 \mathrm{~mL}) \mathbf{4 3}$ was obtained as the tetra(trifluoroacetate) salt $(0.74$ g, ca. $100 \%), R_{f}(J) 0.21$. This salt was used as such for the next step. ESI-MS $(\mathrm{m} / \mathrm{z}): 377.54$ $(M H)$. HR-MS $(\mathrm{m} / \mathrm{z})$ : Found $377.3142\left(\mathrm{M}^{+}+1\right), \mathrm{C}_{18} \mathrm{H}_{41} \mathrm{~N}_{4} \mathrm{O}_{4}$ requires $\mathrm{M}^{+}+1=377.3128$.

$N^{4}, N^{13}$-Di(12'-tritylamino-5',10'-dioxo-4',9'-diazadodecyl)-11,7,10-trioxa-4,13-diaza-

cyclopentadecane (44). To an ice-cold solution of the tetratrifluoroacetate salt $23(0.70 \mathrm{~g}$, $0.89 \mathrm{mmol})$ in anhydrous DMF $(5 \mathrm{~mL}) \mathrm{Et}_{3} \mathrm{~N}(0.77 \mathrm{~mL}, 5.5 \mathrm{mmol})$ was added followed by SAE 6 $(0.92 \mathrm{~g}, 1.8 \mathrm{mmol})$. The resulting reaction mixture was stirred at this temperature for $30 \mathrm{~min}$ and then overnight at ambient temperature. Additional SAE $6(0.10 \mathrm{~g}, 0.2 \mathrm{mmol})$ was then added, and stirring was continued for $1 \mathrm{~d}$. Dilution with EtOAc, washing sequentially with a aqueous $\mathrm{K}_{2} \mathrm{CO}_{3}$ solution (5\%) and with a saturated aqueous $\mathrm{MgSO}_{4}$ solution (twice), drying $\left(\mathrm{MgSO}_{4}\right)$ and evaporation left a residue. This residue was subjected to FCC purification and using solvent system $\mathrm{J}$ as eluant to furnish pure tetra-amide $44(1 \mathrm{~g}, 68 \%)$ as a white foam, $\mathrm{R}_{\mathrm{f}}(\mathrm{L})$ 0.55. FT-IR: $3307(\mathrm{NH}), 1657(\mathrm{NHCO}) \mathrm{cm}^{-1}$. ESI-MS (m/z): 1,169.16 (MK), 1,153.22 (MNa), 1,130.27 (MH), $565.80[(\mathrm{M}+2 \mathrm{H}) / 2] . \mathrm{C}_{68} \mathrm{H}_{88} \mathrm{~N}_{8} \mathrm{O}_{7}$ requires $\mathrm{M}^{+}=1,129.50$.

$N^{4}, N^{16}$-Di(12'-tritylamino-5',10'-dioxo-4', $9^{\prime}$-diazadodecyl)-1,7,10,13-tetraoxa-4,16-diazacyclooctadecane (45). Identical reaction conditions and work-up procedure as for $\mathbf{4 4}$ were employed with the exception of using an aqueous $\mathrm{NaHCO}_{3}$ solution (5\%) instead of $\mathrm{K}_{2} \mathrm{CO}_{3}$. Thus, from the tetratrifluoroacetate salt $43(0.74 \mathrm{~g}, 0.89 \mathrm{mmol})$ after FCC purification using solvent system $\mathrm{K}$ as eluant of pure tetra-amide $45(1.21 \mathrm{~g}, 55 \%)$ was obtained as white foam, $\mathrm{R}_{\mathrm{f}}(\mathrm{K})$ 0.42. FT-IR: $3276(\mathrm{NH}), 1657(\mathrm{NHCO}) \mathrm{cm}^{-1}$. ESI-MS (m/z): 1,213.10 (MK), 1,174.17 $(M \mathrm{H}), 587.76[(\mathrm{M}+2 \mathrm{H}) / 2] . \mathrm{C}_{70} \mathrm{H}_{92} \mathrm{~N}_{8} \mathrm{O}_{8}$ requires $\mathrm{M}^{+}=1,173.55 .{ }^{1} \mathrm{H}$ NMR: $\delta 3.59-3.54$ and 3.276 $\left(16 \mathrm{H}\right.$, two $\left.\mathrm{m}, \mathrm{CH}_{2} \mathrm{O}\right), 2.643\left(8 \mathrm{H}, \mathrm{m}, \mathrm{H}-3^{\prime}\right.$ and $\left.\mathrm{H}-8^{\prime}\right), 2.499,2.409$ and $2.347(12 \mathrm{H}$, three $\mathrm{m}, \mathrm{H}-1$, $\mathrm{H}-6, \mathrm{H}-7, \mathrm{H}-10$ and $\left.\mathrm{H}-\mathrm{1}^{\prime}\right), 2.237$ and $2.128\left(10 \mathrm{H}\right.$, two $\mathrm{m}, \mathrm{NH}, \mathrm{H}-8^{\prime}$ and $\left.\mathrm{H}-11^{\prime}\right), 1.633$ (4H, m, H$\left.2^{\prime}\right), 1.811$ (4H, quintet, $\left.J 6.8 \mathrm{~Hz}, \mathrm{H}-7^{\prime}\right)$.

$N^{4}, N^{13}$-Di[ $\left[N^{4^{\prime}}, N^{9^{\prime}}\right.$-di(tert-butoxycarbonyl)-12'-tritylamino-4' ${ }^{\prime} 9^{\prime}$-diazadodecyl]-11,7,10-trioxa4,13-diaza-cyclopentadecane (47). To a magnetically stirred suspension of $\mathrm{LiAlH}_{4}(0.36 \mathrm{~g}$, $9.6 \mathrm{mmol})$ in refluxing anhydrous THF $(4 \mathrm{~mL})$ a solution of tetra-amide $44(0.9 \mathrm{~g}, 0.8 \mathrm{mmol})$ in THF $(6 \mathrm{~mL})$ was added dropwise within $30 \mathrm{~min}$. Refluxing was continued for $4 \mathrm{~d}$ and then the 
resulting reaction mixture was ice-cooled. Excess $\mathrm{LiAlH}_{4}$ was destroyed carefully by the dropwise addition of a saturated aqueous $\mathrm{K}_{2} \mathrm{SO}_{4}$ solution, the precipitated salts were filtered off and washed on the filter with distilled THF. The filtrate was evaporated under reduced pressure and the residue was taken-up in EtOAc and was washed twice with a saturated aqueous $\mathrm{KCl}$ solution. Drying $\left(\mathrm{MgSO}_{4}\right)$, filtration and evaporation left the crude product $46(0.73 \mathrm{~g}$, $0.68 \mathrm{mmol})$. ESI-MS (m/z): 1,074.36 (MH). This product was dissolved in anhydrous $\mathrm{CHCl}_{3}$ $(3 \mathrm{~mL})$ and treated sequentially at $0{ }^{\circ} \mathrm{C}$ with $\mathrm{Et}_{3} \mathrm{~N}(0.57 \mathrm{~mL}, 4.08 \mathrm{mmol})$, a catalytic amount of DMAP and $\mathrm{Boc}_{2} \mathrm{O}(0.74 \mathrm{~g}, 3.4 \mathrm{mmol})$ and was then left at ambient temperature overnight. Dilution with $\mathrm{CHCl}_{3}$, sequential washing once with a $5 \%$ aqueous $\mathrm{K}_{2} \mathrm{CO}_{3}$ solution and with $\mathrm{H}_{2} \mathrm{O}$ (twice), drying $\left(\mathrm{MgSO}_{4}\right)$, filtration and evaporation left an oily residue. From this residue, after FCC purification with solvent system I as eluant pure product $47(0.41 \mathrm{~g}, 35 \%$ overall yield based on tetra-amide 44) was obtained as a foam, $\mathrm{R}_{\mathrm{f}}(\mathrm{J})$ 0.34. ESI-MS $(\mathrm{m} / \mathrm{z}): 1,475.62(M H)$. HR-MS $(\mathrm{m} / \mathrm{z})$ : Found 1,473.9772 $\left(\mathrm{M}^{+}+1\right), \mathrm{C}_{88} \mathrm{H}_{129} \mathrm{~N}_{8} \mathrm{O}_{11}$ requires $\mathrm{M}^{+}+1=1,473.9781$.

$N^{4}, N^{13}$-Di(12'-amino-4',9'-diazadodecyl)-11,7,10-trioxa-4,13-diazacyclopentadecane (48). A solution of fully protected octa-amine derivative $47(0.41 \mathrm{~g}, 0.28 \mathrm{mmol})$ in $\mathrm{CH}_{2} \mathrm{Cl}_{2} / \mathrm{TFA}(1: 1 ; 4 \mathrm{~mL})$ was kept at ambient temperature for 20 min. Evaporation to dryness, trituration with $\mathrm{Et}_{2} \mathrm{O}$ and overnight refrigeration gave the octatrifluoroacetate salt of octa-amine $48(0.37 \mathrm{~g}, 88 \%)$ as a foam, $\mathrm{R}_{\mathrm{f}}(\mathrm{L})$ 0.19. HR-MS (m/z): Found $589.5498\left(\mathrm{M}^{+}+1\right), \mathrm{C}_{30} \mathrm{H}_{69} \mathrm{~N}_{8} \mathrm{O}_{3}$ requires $\mathrm{M}^{+}+1=$ 589.5493.

$N^{4}, N^{16}$-Di $\left[N^{4^{\prime}}, N^{9}\right.$-di(tert-butoxycarbonyl)-12'-tritylamino-4', $9^{\prime}$-diazadodecyl]-1,7,10,13-

tetraoxa-4,16-diazacyclooctadecane (50). Identical reaction conditions and work-up procedure, with the exception that $\mathrm{Na}_{2} \mathrm{SO}_{4}$ was used instead of both $\mathrm{K}_{2} \mathrm{SO}_{4}$ and $\mathrm{KCl}$, as for the preparation of 46 were used for the preparation of product 49. Thus, from of tetra-amide $45(0.9 \mathrm{~g}$, $0.77 \mathrm{mmol})$ the crude product $49(0.4 \mathrm{~g})$ was obtained. ESI-MS $(\mathrm{m} / \mathrm{z}): 1,119.49(\mathrm{MH}), 1,118.48$ $(M), 560.55[(\mathrm{M}+2 \mathrm{H}) / 2]$. This product was directly converted into the corresponding per(tertbutoxycarbonylated) oily product $50(0.3 \mathrm{~g}, 26 \%$ overall yield based on the tetra-amide $45 \mathrm{~b})$ after FCC purification with solvent system $J$ as eluant. $\mathrm{R}_{\mathrm{f}}(\mathrm{J})$ 0.22. ESI-MS $(\mathrm{m} / \mathrm{z}): 1,519.96(\mathrm{MH})$. HR-MS (m/z): Found 1,518.0031 $\left(\mathrm{M}^{+}+1\right), \mathrm{C}_{90} \mathrm{H}_{133} \mathrm{~N}_{8} \mathrm{O}_{12}$ requires $\mathrm{M}^{+}+1=1,518.0043$.

$N^{4}, N^{16}$-Di(12'-amino-4',9'-diazadodecyl)-1,7,10,13-tetraoxa-4,16-diazacyclooctadecane (51). A solution of fully protected octa-amine derivative $\mathbf{5 0}(0.3 \mathrm{~g}, 0.2 \mathrm{mmol})$ in $\mathrm{CH}_{2} \mathrm{Cl}_{2} / \mathrm{TFA}(1: 1 ; 4 \mathrm{~mL})$ was kept at ambient temperature for $20 \mathrm{~min}$. Evaporation to dryness, trituration with $\mathrm{Et}_{2} \mathrm{O}$ and overnight refrigeration gave the octa(trifluoroacetate) salt of octa-amine $\mathbf{5 1}(0.25 \mathrm{~g}, 83 \%)$ as a thick oil, $\mathrm{R}_{\mathrm{f}}(\mathrm{L})$ 0.19. HR-MS (m/z): Found $633.5767\left(\mathrm{M}^{+}+1\right), \mathrm{C}_{32} \mathrm{H}_{73} \mathrm{~N}_{8} \mathrm{O}_{4}$ requires $\mathrm{M}^{+}+1=$ 633.5755 .

\section{Acknowledgements}

The Research Committee of the University of Patras is gratefully acknowledged for the financial support of this project in the context of the basic research programme ' $\mathrm{K}$. Karatheodoris'. 


\section{References}

1. (a) Karigiannis, G.; Papaioannou, D. Eur J. Org. Chem. 2000, 1841. (b) Kuksa, V.; Buchan, R.; Kong Thoo Lin, P. Synthesis 2000, 1189. (c) Theodorides, G. Tetrahedron 2000, 56, 2339. (d) Polyamine Protocols In Methods in Molecular Biology, Morgan, D. M. L., Humana Press: Totowa: New Jersey, 1998. (e) Blagbrough, I. S.; Carrington, S.; Geall, A. J. Pharm. Sci. 1997, 3, 223. (f) Schulz, S. Angew. Chem., Int. Ed. 1997, 36, 314 and references cited therein.

2. For selected reviews/monographs/articles on CEs and related systems see: (a) Balzani, V.; Credi, A.; Raymo, F. M.; Stoddart, J. F. Angew. Chem., Int. Ed. 2000, 39, 3349. (b) Schneider, H.-J.; Yatsimirsky, A. Principles and Methods in Supramolecular Chemistry, Wiley: Chichester, 2000. (c) Zhang, X. X.; Bradshaw, J. S.; Izatt, R. M. Chem. Rev 1997, 97, 3313. (d) Macrocycle Synthesis-A Practical Approach In The Practical Approach in Chemistry Series, Parker, D., Ed.; Oxford University Press: Oxford, 1996. (e) Izatt, R. M.; Pawlak, K.; Bradshaw, J. S.; Bruening, R. L. Chem. Rev. 1995, 95, 2529. (f) Lehn, J. M. Supramolecular Chemistry: Concepts and Perspectives, VCH: Weinheim, 1995. (g) Izatt, R. M.; Pawlak, K.; Bradshaw, J. S.; Bruening, R. L. Chem. Rev. 1991, 91, 1721. (h) Gokel, G. W. Crown Ethers and Cryptands, Royal Society of Chemistry: Cambridge, 1991. (i) Vögtle, F. Supramolecular Chemistry; Wiley: New York, 1991. (j) Dishong, D. M.; Diamond, C. J.; Cinoman, M. I.; Gokel, G. W. J. Am. Chem. Soc. 1983, 105, 586. (k) Bradshaw, J. S.; Stott, P. E. Tetrahedron 1980, 36, 461. (1) Vögtle, F.; Weber, E. Angew. Chem., Int. Ed. 1979, 18, 753. (m) Gokel, G. W.; Durst, H. D. Synthesis 1976, 168. (n) Pedersen, C. J. J. Am. Chem. Soc. 1967, 89, 7017.

3. For selected examples of CEs bearing pharmacophoric groups see (a) White, B. D.; Arnold, K. A.; Gokel, G. W. Tetrahedron Lett. 1987, 28, 1749. (b) Sosnovsky, G.; Lukszo, J.; Uma Maheswara Rao, N. J. Med. Chem. 1986, 29, 1250. (c) Jarvis, B. B.; Vrudhula, V. M.; Dishong, D. M.; Gokel, G. W. J. Org. Chem. 1984, 49, 2423. (d) Berthet, M.; Sonveaux, E. J. Chem. Soc., Chem. Commun. 1983, 10. (e) Newkome, G. R.; Lee. H.-W.; J. Org. Chem. 1982, 47, 2800. (f) Fenton, D. E.; Parkin, D.; Newton, R. F. J. Chem. Soc., Perkin I 1981, 449. (g) Vögtle, F.; Elben, U. Chem. Ber. 1978, 111, 1434. (h) Vögtle, F.; Jansen, B. Tetrahedron Lett. 1976, 4895. (i) Vögtle, F.; Frensch, K. Angew. Chem., Int. Ed. 1976, 15, 685.

4. Part of this work has been presented in the following review article: Tsiakopoulos, N.; Vassis, S.; Militsopoulou, M.; Damianakos, C.; Gatos, P.; Voyatzi, K.; Pantazaka, E.; Papaioannou, D. Drug Discovery and Design: Medical Aspects In Biomedical and Health Research, Matsoukas, J.; Mavromoustakos, T. Eds; IOS Press: Amsterdam, 2002; Vol. 55, p 53.

5. (a) Karigiannis, G.; Mamos, P.; Balayiannis, G.; Katsoulis, I.; Papaioannou, D. Tetrahedron Lett. 1998, 39, 5117. (b) Vassis, S.; Karigiannis, G.; Balayiannis, G.; Militsopoulou, M.; Mamos, P.; Francis, G. W.; Papaioannou, D. Tetrahedron Lett. 2001, 42, 1579. 
6. (a) Militsopoulou, M.; Tsiakopoulos, N.; Chochos, C.; Magoulas, G.; Papaioannou, D. Tetrahedron Lett. 2002, 43, 2593. (b) Vassis, S.; Govaris, I.; Voyatzi, K.; Mamos, P.; Papaioannou, D. Tetrahedron Lett. 2002, 43, 2597. (c) Mamos, P.; Karigiannis, G.; Athanassopoulos, K.; Bichta, S.; Kalpaxis, D.; Papaioannou, D. Tetrahedron Lett. 1995, 36, 5187.

7. Barlos, K.; Papaioannou, D.; Theodoropoulos, D. J. Org. Chem. 1982, 47, 1324.

8. Krakowiak, K. E.; Bradshaw, J. S. Synth. Commun. 1998, 28, 3451.

9. See ref. 1b, pp.1203-1206 and references cited therein as well as the following articles on polyamines incorporating linear poly(ethylene glycol) residues: (a) Garrett, S. W.; Davies, O R.; Milroy, D. A.; Wood, P. J.; Threadgill, M. D. Bioorg. Med. Chem. 2000, 8, 1779. (b) Fan, E. K.; Zhang, Z. S.; Minke, W. E.; Hou, Z.; Verlinde, C. M. L. J.; Hol, W. G. J. J. Am. Chem. Soc. 2000, 122, 2663

10. Chang, C. K. J. Am. Chem. Soc. 1977, 99, 2819.

11. Artuso, F.; Sindona, G.; Athanassopoulos, C.; Stavropoulos, G.; Papaioannou, D. Tetrahedron Lett. 1995, 36, 9309.

12. Bubnis, B. P.; Pacey, G. E. Tetrahedron Lett. 1984, 25, 1107.

13. Maeda, H.; Kikui, T.; Nakatsuji, Y.; Okahara, M. J. Org. Chem. 1982, 47, 5167.

14. Laguerre, M.; Boyer, C.; Leger, J.-M.; Carpy, A. Can. J. Chem. 1989, 67, 1514.

15. (a) Yamato, K.; Bartsch, R. A.; Dietz, M. L.; Rogers, R. D. Tetrahedron Lett. 2002, 43, 2153. (b) Jungk, S. J.; Moore, J. A.; Gandour, R. D. J. Org. Chem. 1983, 48, 1116. (c) Jolly, S. T.; Bradshaw, J. S. J. Org. Chem. 1980, 45, 3554. (d) Ikeda, I.; Yamamura, S.; Nakatsuji, Y.; Okahara, M. J. Org. Chem. 1980, 45, 5355.

16. Ouchi, M.; Inoue, Y.; Liu, Y.; Nagamune, S.; Nakamura, S.; Wada, K.; Hakushi, K. Bull. Chem. Soc. Jpn. 1990, 63, 1260.

17. Huber, V. J.; Dietz, M. L. Tetrahedron Lett. 2001, 42, 2945.

18. Manimala, J. C.; Anslyn, E. V. Eur. J. Org. Chem. 2002, 3909 and references cited therein.

19. See ref. 2d, pp 39-42 and the following references cited therein: (a) Amble, E.; Dale, J. Acad. Chem. Scand. 1979, B33, 698. Calverley, M. J.; Dale, J. Acad. Chem. Scand. 1982, B36, 241. (b) Kataky, R.; Matthes, K. E.; Nicholson, P. E.; Parker, D.; Buschmann, H. J. J. Chem. Soc., Perkin Trans. 2 1990, 1425. (c) Gatto, V. J.; Gokel, G. J. Am. Chem. Soc. 1984, 106, 8240. (d) Gatto, V. J.; Miller, S. R.; Gokel, G. Org. Synth. 1989, 68, 227. 